\title{
Sulfur trioxide formation/emissions in coal-fired air- and oxy-fuel combustion processes: a review
}

\author{
Yerbol Sarbassov, Cranfield University, UK \\ Duan Lunbo, Southeast University, China \\ Vasilije Manovic, Cranfield University, UK \\ Edward J. Anthony, Cranfield University, UK
}

Correspondence to: Edward J. Anthony; Combustion and CCS Centre, Bedford MK43 0AL, Bedfordshire, UK. E-mail: b.j.anthony@cranfield.ac.uk

\begin{abstract}
In oxy-fuel combustion, fuel is burned using oxygen together with recycled flue gas which is needed to control the combustion temperature. This leads to higher concentrations of sulfur dioxide and sulfur trioxide in the recycled gas that can result in the formation of sulfuric acid and enhanced corrosion. Current experimental data on $\mathrm{SO}_{3}$ formation, reaction mechanisms, and mathematical modelling have indicated significant differences in $\mathrm{SO}_{3}$ formation between air- and oxy-fuel combustion for both the wet and dry flue gas recycle options. This paper provides an extensive review of sulfur trioxide formation in air- and oxy-fuel combustion environments, with an emphasis on coal-fired systems. The first part summarizes recent findings on oxy-fuel combustion experiments, as they affect sulfur trioxide formation. In the second part, the review focuses on sulfur trioxide formation mechanisms, and the influence of catalysis on sulfur trioxide formation. Finally, the current methods for measuring sulfur trioxide concentration are also reviewed along with the major difficulties associated with those measurements using data available from both bench- and pilot-scale units.
\end{abstract}

Keywords: Oxy-fuel combustion, sulfur dioxide, sulfur trioxide formation, catalysis 


\section{Table of Contents}

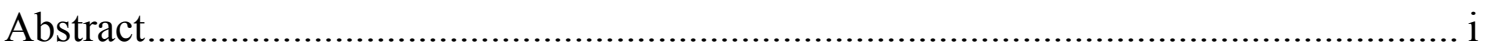

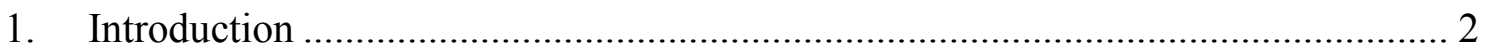

1.1 Oxy-fuel Combustion Technology ............................................................... 2

1.2 Influence of Sulfur in Combustion Systems .................................................. 4

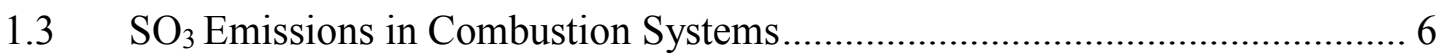

1.4 Objectives and Scope of the Paper ......................................................... 8

2. Oxy-Fuel Combustion Environment …………………................................... 9

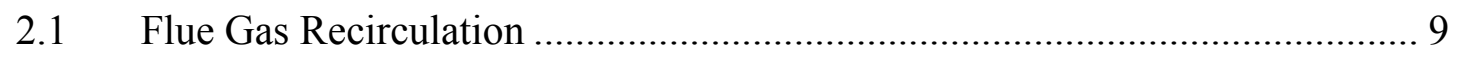

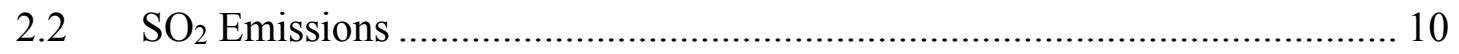

3. Background for $\mathrm{SO}_{3}$ Formation in Combustion .................................................... 11

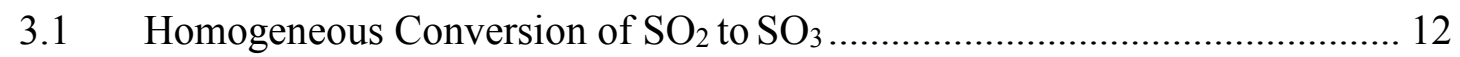

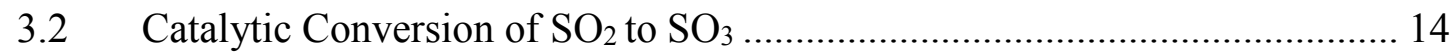

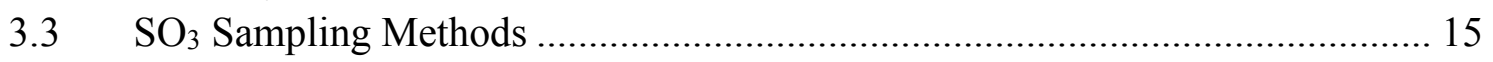

3.3.1 Controlled condensation method ............................................................ 15

3.3.2 Isopropanol absorption bottle method ………………………………..... 17

3.3.3 Salt and glass bead methods ................................................................. 18

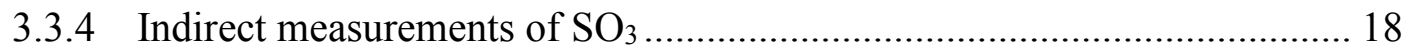

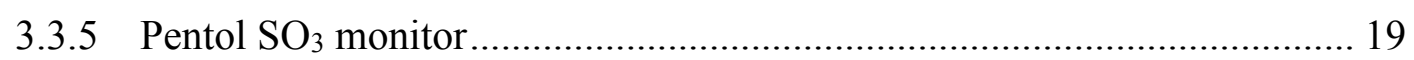

3.3.6 Acid dew point measurements............................................................... 20

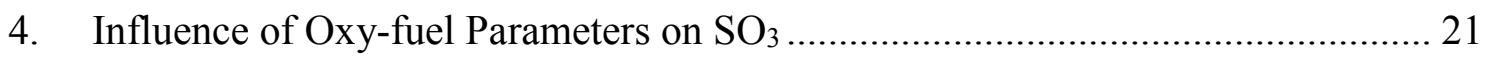

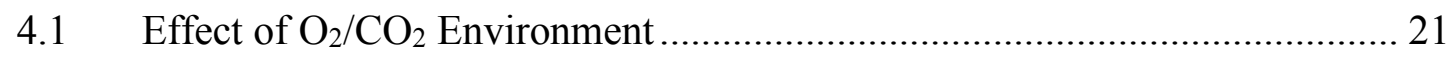

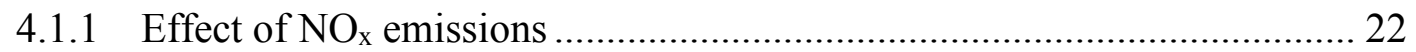

4.1.2 Effect of carbon monoxide ……………………………......................... 23

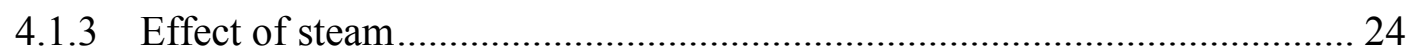

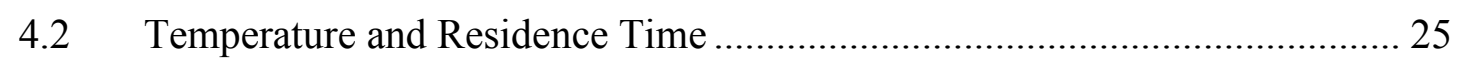

4.3 Catalytic Effect of Fly Ash .................................................................. 28

$4.4 \quad \mathrm{SO}_{3}$ Emissions from Pilot-scale Studies ........................................................ 30



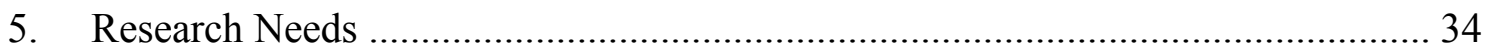

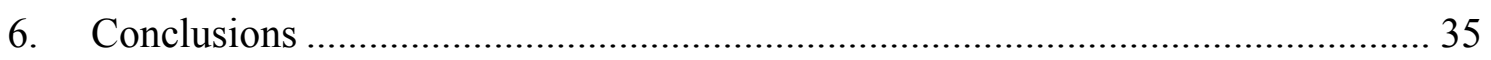

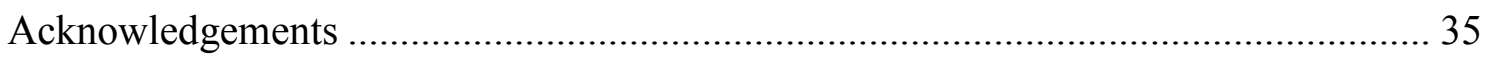




\section{Introduction}

\subsection{Oxy-fuel Combustion Technology}

According to the International Energy Agency (IEA), 41\% of the electricity generated in 2013 was produced from coal-fired power stations, ${ }^{1}$ while data for 2015 indicated that about $45 \%$ of the anthropogenic $\mathrm{CO}_{2}$ was produced from coal. ${ }^{2}$ Current energy utilization trends indicate that energy generated from fossil fuels will continue to play an important role in the world energy portfolio in the foreseeable future. In this context, carbon capture and storage (CCS) has been proposed as a strategy to mitigate greenhouse gas emissions (GHG) from fossil fuel-fired power plants and industrial processes, and the Intergovernmental Panel on Climate Change (IPCC) suggests that CCS could potentially reduce $\mathrm{CO}_{2}$ emissions from those systems by 80$90 \%{ }^{3}$ CCS technology involves production of a highly concentrated $\mathrm{CO}_{2}$ stream from a combustion process which can be transported to and stored in geological formations such as saline aquifers or depleted oil and gas reservoirs. Oxy-fuel combustion was initially proposed in 1982, to produce highly concentrated flue gas $\left(\mathrm{CO}_{2}\right)$ for enhanced oil recovery (EOR). ${ }^{4,5}$ The concept was later explored by Argonne National Laboratory (ANL), where oxy-fuel tests were carried out at a pilot-scale facility. ${ }^{6}$ In 1990, comprehensive work started on CCS concepts throughout Europe and the USA. ${ }^{7,8}$ A simplified block diagram of oxy-fuel CCS systems is presented in Fig. 1, in which the most important feature of the process is that fuel is burned in a mixture of $\mathrm{O}_{2}$ and $\mathrm{CO}_{2}$ and steam from flue gas recycle (FGR) in order to moderate combustion temperatures to the same level as in an air-fired unit. As combustion occurs in the

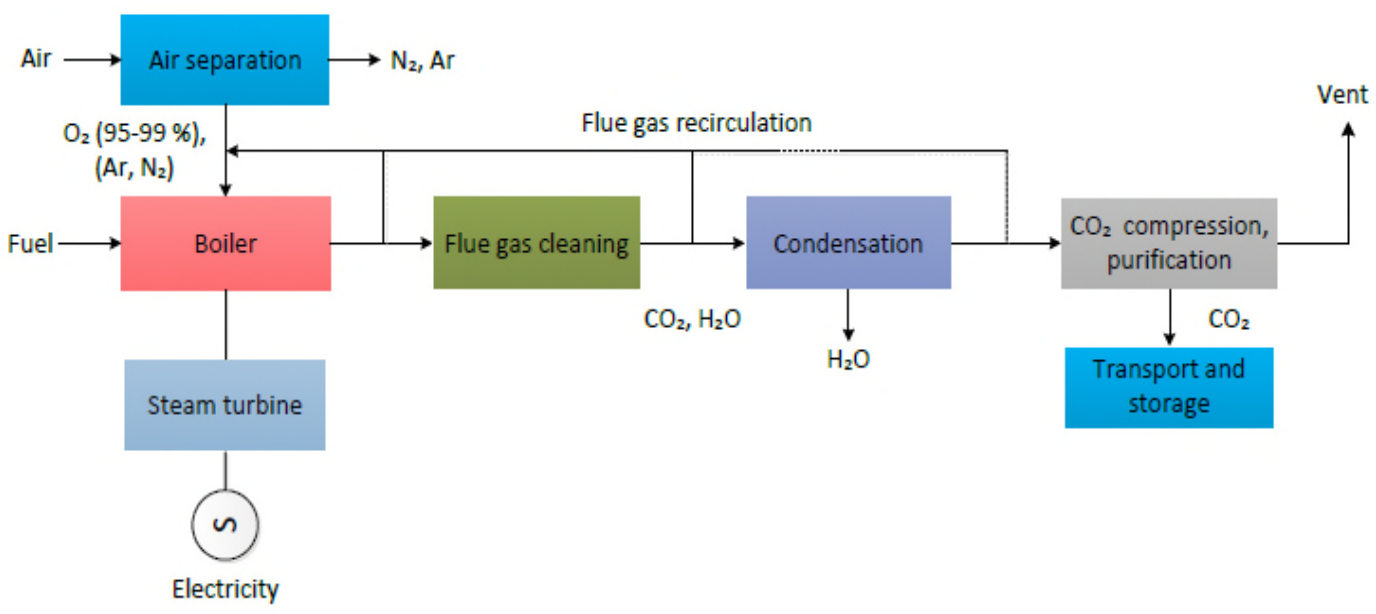

Figure 1 Principal scheme of oxy-fuel combustion process 
effective absence of nitrogen, the flue gas consists mainly of $\mathrm{CO}_{2}$ and steam, with impurities such as $\mathrm{NO}_{\mathrm{x}}$ and $\mathrm{SO}_{\mathrm{x}}$. The composition of the concentrated $\mathrm{CO}_{2}$ stream from oxy-fuel combustion was studied by Liu and Shao, ${ }^{9}$ who found that $\mathrm{N}_{2} / \mathrm{Ar}$ and $\mathrm{O}_{2}$ concentrations typically varied from 1-6\%, and 3-5\%, respectively, depending on $\mathrm{O}_{2}$ purity from the air separation unit (ASU) and the equivalence ratio. Also, the steam concentration in the flue gas was in the range of $10-40 \%$, depending on the fuel properties and FGR. ${ }^{9}$ Typical emissions from coal- and gas-fired power plants are reported by the IEA (Table 1). ${ }^{10}$ Circulating fluidized bed combustion (CFBC) offer comparatively lower $\mathrm{SO}_{2}$ and $\mathrm{NO}_{\mathrm{x}}$ emissions, and in the case of pulverized coal (PC) technologies additional flue gas clean-up is required.

Table 1 Performance of coal- and natural gas-fired power plants

\begin{tabular}{|c|c|c|c|c|c|c|}
\hline Plant (MW) & $\begin{array}{l}\text { Capacity } \\
\text { factor } \\
(\%)\end{array}$ & $\begin{array}{l}\mathrm{CO}_{2} \\
(\mathrm{~g} / \mathrm{kWh})\end{array}$ & $\begin{array}{l}\mathbf{N O}_{\mathbf{x}} \\
\left(\mathbf{m g} / \mathbf{N m}^{3}\right)\end{array}$ & $\begin{array}{l}\mathrm{SO}_{2} \\
\left(\mathrm{mg} / \mathbf{N m}^{3}\right)\end{array}$ & $\begin{array}{l}\mathbf{P M}^{1} \\
\left(\mathbf{m g} / \mathbf{N m}^{3}\right)\end{array}$ & $\begin{array}{l}\text { Efficiency } \\
\text { penalty } \\
\text { (CCS) }(\%)\end{array}$ \\
\hline $\begin{array}{l}\text { PC-Ultra } \\
\text { Super Critical } \\
(1050)^{2}\end{array}$ & 80 & 740 & $\begin{array}{l}<50 \text { to } 100 \\
\text { (by SCR) }\end{array}$ & $\begin{array}{l}<20 \text { to } 100 \\
\text { (by FGD) }\end{array}$ & $<10$ & \multirow{3}{*}{$\begin{array}{l}7 \text { to } 10 \\
\text { (post- and } \\
\text { oxy-fuel } \\
\text { combustion) }\end{array}$} \\
\hline $\mathrm{CFBC}(460)^{3}$ & 80 & $\begin{array}{l}880 \text { to } \\
900\end{array}$ & $<200$ & $\begin{array}{l}<50 \text { to } 100 \\
\text { (in situ) }\end{array}$ & $<50$ & \\
\hline $\begin{array}{l}\text { PC A-Ultra } \\
\text { Super } \\
\text { Critical }^{4} \\
<(1000)\end{array}$ & - & 669 & $\begin{array}{l}<50 \text { to } 100 \\
\text { (by SCR) }\end{array}$ & $\begin{array}{l}<20 \text { to } 100 \\
\text { (by FGD) }\end{array}$ & $<10$ & \\
\hline IGCC (335) & 70 & $\begin{array}{l}669 \text { to } \\
740\end{array}$ & $<30$ & $<20$ & $<1$ & 7 \\
\hline NGCC (410) & 80 & 400 & $<20$ & Almost none & 0 & 8 \\
\hline
\end{tabular}

1. Particulate matter, 2. In operation (sliding pressure-type), 3. In operation (Poland), 4. Under development.

The flue gas passes through a cleaning process comprised of a series of steps, such as particle removal by an electrostatic precipitator (ESP), flue gas desulfurization (FGD) and selective catalytic reduction (SCR). The ESP system also prevents degradation of catalysts in the SCR unit. In addition, to avoid an accumulation of sulfur species in the SCR system, an FGD unit must be installed upstream of the SCR unit. ${ }^{4}$ Studies to date suggest that due to $\mathrm{O}_{2}$ separation, flue gas treatment and $\mathrm{CO}_{2}$ compression, the net efficiency of oxy-fuel systems drops $7-11 \%$ points. ${ }^{11-13}$ This increases the levelized cost of energy from such systems, which also significantly varies depending on the plant location, type of fuel and other assumptions used for evaluations. ${ }^{11}$ 
The purified $\mathrm{CO}_{2}$ stream is then compressed and transported for geological storage. ${ }^{14-19}$ Anheden et al. ${ }^{15}$ reported that the $\mathrm{SO}_{2}$ content in the $\mathrm{CO}_{2}$ stream must be $<200 \mathrm{mg} / \mathrm{Nm}^{3}$, or even as low $<50 \mathrm{mg} / \mathrm{Nm}^{3}$, depending on $\mathrm{CO}_{2}$ storage site requirements. Markewitz et al. ${ }^{18}$ recommended that $\mathrm{SO}_{\mathrm{x}}$ concentrations for $\mathrm{CO}_{2}$ transportation should be kept below 100 ppm in order to reduce corrosion issues. ${ }^{19}$ Also, $\mathrm{SO}_{2}$ in the $\mathrm{CO}_{2}$ stream may cause problems due to sulfation of calcium-containing minerals and formation of sulfates which decrease the permeability and may affect the storage capacity of the reservoir. In addition, nearly complete dehydration of the $\mathrm{CO}_{2}$ stream is strongly desirable in order to inhibit corrosion, ${ }^{20,21}$ and removal of various other impurities is necessary since they negatively affect all stages in the CCS chain. ${ }^{22,23}$

Typical contents of impurities in CCS systems are shown in Table 2, specifically for three oxygen-purity scenarios for oxy-fuel technologies, resulting in $85.0 \%, 98.0$ and $99.9 \% \mathrm{CO}_{2}$ in the flue gas stream, respectively. ${ }^{24,25}$ It can be seen that $\mathrm{SO}_{2}$ and $\mathrm{SO}_{3}$ concentrations in the $\mathrm{CO}_{2}$ streams are higher in oxy-fuel combustion than in the pre-combustion and post-combustion schemes. White et al. ${ }^{26}$ have highlighted that the $\mathrm{SO}_{2}$ and $\mathrm{SO}_{3}$ compounds can be removed from the $\mathrm{CO}_{2}$ stream during the compression stage in the form of $\mathrm{H}_{2} \mathrm{SO}_{4}$ and that additional purification of the raw $\mathrm{CO}_{2}$ stream is not required.

As stated above, sulfur species derived from coal-fired power plants are a major issue. Sulfur removal by limestone has been found to be an effective option to control $\mathrm{SO}_{\mathrm{x}}$ emissions due to low capital and operational costs. ${ }^{27,28}$ However, this option is not practical for PC boilers due to higher flame temperatures causing thermal decomposition of sulfation products $\left(\mathrm{CaSO}_{4}\right){ }^{27,28}$ Recently, impacts of sulfur in oxy-fired PC boilers have been reviewed by Stanger et al. ${ }^{29}$, and they noted that the formation of $\mathrm{SO}_{3}$ is a major issue in coal-fired combustion boilers. However, there is less research on this issue for oxy-fuel combustion in fluidized bed combustion (FBC) boilers despite the fact that increased $\mathrm{SO}_{2}$ and $\mathrm{SO}_{3}$ concentrations are expected due to FGR and more pronounced corrosion issues on downstream surfaces are expected due to lower gas flow rates through the furnace. ${ }^{30,31}$ This paper aims to provide a major overview of the subject of $\mathrm{SO}_{3}$ formation and its emissions from air and oxy-fired boilers, given that at this time no such review exists.

\subsection{Influence of Sulfur in Combustion Systems}

The sulfur content in coal may vary from 0.2 to $11 \%$, depending on the location and rank. ${ }^{32,33}$ However, the values fall generally between 0.3 and $4.3 \% .{ }^{34}$ Typically, sulfur in coal is 
classified as organic and inorganic. ${ }^{32,35}$ The amount of organic sulfur is typically approximately one-half to one-third of the total. ${ }^{35,36}$ Most organic and pyritic sulfur in coal is converted to $\mathrm{SO}_{2}$ during combustion and only a small fraction of the sulfur is retained in the ash. ${ }^{27}$ For example, studies for North Dakota coals showed 83 to $93 \%$ sulfur conversion to $\mathrm{SO}_{2}$, depending on sulfur content and forms of sulphur in coal. ${ }^{37}$ Similarly, $91 \%$ of sulfur conversion for a US eastern bituminous coal was observed by Croiset and Thambimuthu. ${ }^{38}$ German lignite was also investigated in a pilot-scale $100 \mathrm{~kW}$ oxy-PC unit at Chalmers University and showed $67 \%$ conversion. ${ }^{39}$ During combustion, part of the sulfur is retained in the fly ash by reacting with alkaline and alkaline earth metal compounds such as calcium carbonates, and sodium chloride. ${ }^{40}$ Sulfur retention by the alkaline compounds is typically roughly 10 to $15 \% .{ }^{37,40}$ It has been reported that the sulfur retention in PC boilers and fluidized beds are different mainly due to different combustion temperatures. ${ }^{41}$ Inorganic constituents of several Australian lowrank coals and ash characteristics (after combustion in a laboratory-scale fluidized bed) were investigated and it was noted that combustion of coals with high sulfur and sodium contents resulted in formation of low-melting-point compounds such as alkali sulfates in the ash, which are deposited as a coating on bed material surfaces. ${ }^{42}$ This process can also cause bed material to become sticky and enhance ash build-up in the reactor. Coals with low sulfur and sodium content permit operation over a much longer time without any agglomeration and defluidization. ${ }^{42}$

Table 2 Composition of $\mathrm{CO}_{2}$ streams for storage

\begin{tabular}{lllllllll}
\hline Species & \multicolumn{3}{l}{ Pre-combustion } & \multicolumn{3}{l}{ Post-combustion } & \multicolumn{3}{l}{ Oxy-fuel } \\
\cline { 2 - 9 } & Selexol & Rectisol & $\begin{array}{l}\text { Purity } \\
\text { Low }\end{array}$ & $\begin{array}{l}\text { Purity } \\
\text { Med. }\end{array}$ & $\begin{array}{l}\text { Purity } \\
\text { High }\end{array}$ & $\begin{array}{l}\text { Purity } \\
\text { Low }\end{array}$ & $\begin{array}{l}\text { Purity } \\
\text { Med. }\end{array}$ & $\begin{array}{l}\text { Purity } \\
\text { High }\end{array}$ \\
\hline $\mathrm{CO}_{2}(\mathrm{vol} \%)$ & 97.95 & 99.7 & 99.93 & 99.92 & 99.81 & 85.00 & 98.00 & 99.94 \\
$\mathrm{O}_{2}($ vol\%) & & & 0.015 & 0.015 & 0.03 & 4.70 & 0.67 & 0.01 \\
$\mathrm{~N}_{2}(\mathrm{vol} \%)$ & 0.90 & 0.21 & $0.045^{1}$ & $0.045^{1}$ & $0.09^{1}$ & 5.80 & 0.71 & 0.01 \\
$\mathrm{Ar}(\mathrm{vol} \%)$ & 0.03 & 0.15 & & & & 4.47 & 0.59 & 0.01 \\
$\mathrm{H}_{2} \mathrm{O}(\mathrm{ppm})$ & 600 & 10 & 100 & 100 & 600 & 100 & 100 & 100 \\
$\mathrm{NO}_{\mathrm{x}}(\mathrm{ppm})$ & & & 20 & 20 & 20 & 100 & 100 & 100 \\
$\mathrm{SO}_{2}(\mathrm{ppm})$ & & & $10^{2}$ & $10^{2}$ & $20^{2}$ & 50 & 50 & 50 \\
$\mathrm{SO}_{3}(\mathrm{ppm})$ & & & & & & 20 & 20 & 20 \\
$\mathrm{CO}(\mathrm{ppm})$ & 400 & 400 & 10 & 10 & 20 & 50 & 50 & 50 \\
$\mathrm{H}_{2} \mathrm{~S}+\mathrm{COS}$ & 100 & 100 & & & & & & \\
$(\mathrm{ppm})$ & & & & & & & & \\
\hline
\end{tabular}

\footnotetext{
${ }^{1}$ Total concentration of $\mathrm{N}_{2}$ and $\mathrm{Ar} ;{ }^{2}$ Total concentrations of $\mathrm{SO}_{2}$ and $\mathrm{SO}_{3}$
} 
The main challenge with burning sulfur-containing coals is corrosion, which has been extensively studied in the case of conventional, ${ }^{32,33,40}$ and more recently, in oxy-fuel combustion systems. ${ }^{29}$ Most of the corrosion mechanisms associated with sulfur in aircombustion are well explored and apply equally well to oxy-combustion. Corrosion is caused by low-temperature-melting alkali salt deposits when burning coals rich in sulfur, chlorine and sodium compounds. ${ }^{43}$ Longer operation of the units can lead to damage of heat exchangers by loss of metal or formation of cracks in high-temperature zones. ${ }^{44}$ The presence of pyrite in coal is the main reason for the formation of clinkers when high-sulfur coals rich in pyrites $\left(\mathrm{FeS}_{2}\right)$ were burned..$^{43}$ Under such conditions, iron species occurring in high-sulfur coals act as fluxing agents, and enhance the melting of quartz and clays in the coal. ${ }^{43}$ In addition, elevated levels of $\mathrm{SO}_{3}$ in the molten salt result in an increase in solubility of the oxide scale on the metal. ${ }^{45,46}$

\section{3 $\mathrm{SO}_{3}$ Emissions in Combustion Systems}

Formation of $\mathrm{SO}_{3}$ is undesirable in combustion processes as it enhances low-temperature corrosion and formation of aerosol emissions. ${ }^{30} \mathrm{By}$ its nature, $\mathrm{SO}_{3}$ is very reactive and converts easily to sulfuric acid in the presence of water vapour. ${ }^{35}$ Formation of $\mathrm{SO}_{3}$ is thermodynamically favoured at lower temperatures; however, cooling rates in practical systems retard the $\mathrm{SO}_{3} / \mathrm{SO}_{2}$ conversion rate. $\mathrm{Moser}^{47}$ reported that the deposition of $\mathrm{H}_{2} \mathrm{SO}_{4}$ on downstream surfaces can be avoided by increasing the outlet temperature of the flue gas. Doing so, for example, by increasing the flue gas temperature in the air heater by $1.7^{\circ} \mathrm{C}$ can result in an improvement of nearly $1 \%$ in the unit heat rate. ${ }^{47}$ The annual benefit derived from the removal of $\mathrm{SO}_{3}$ and the consequential reduction of corrosion downstream can exceed $\$ 500,000$ for a $500 \mathrm{MW}$ unit. ${ }^{47}$ During combustion, most sulfur in fuel is oxidised to $\mathrm{SO}_{2}$, while a limited amount of $\mathrm{SO}_{2}$ may be converted to $\mathrm{SO}_{3} .{ }^{30,34,35,38}$ In addition, 0.5 to $1.5 \mathrm{wt} \%$ of $\mathrm{SO}_{2}$ present in the flue gas may further oxidize to $\mathrm{SO}_{3}{ }^{48}$ The $\mathrm{SO}_{2}$-to- $-\mathrm{SO}_{3}$ conversion is dependent on several parameters such as: combustion temperature, $\mathrm{O}_{2}$ concentration and the presence of catalytic compounds in the fly ash. ${ }^{49,50}$ Tan et al. ${ }^{51}$ have stated that the oxidation of $\mathrm{SO}_{2}$ to $\mathrm{SO}_{3}$ in typical PC boilers may reach 5\%, depending on the sulfur content of the coal. Data from the UK power plants shown in Table $3^{52}$ indicate the effect of excess $\mathrm{O}_{2}$ concentrations on the formation of $\mathrm{SO}_{3}$. It can be seen that operation under low $\mathrm{O}_{2}$ concentration in the flue gas leads to significantly lower levels of $\mathrm{SO}_{3}$.

SCR technology in coal-fired power plants can cause further oxidation of $\mathrm{SO}_{2}$ to $\mathrm{SO}_{3}{ }^{30,47}$ According to Moser, ${ }^{47}$ this $\mathrm{SO}_{2}$ oxidation to $\mathrm{SO}_{3}$ in $\mathrm{SCR}$ can vary from $0.3 \%$ to $2 \%$. Slightly lower values for bituminous coals $(0.25-0.5 \%)$ compared to that of for sub-bituminous coals 
( 0.75 to $1.25 \%$ ) were noted by Srivastava et al. ${ }^{30}$ A more detailed study on $\mathrm{SO}_{2}$ oxidation over honeycomb SCR catalysts was presented by Svachula et al. ${ }^{53}$ According to these authors, the oxidation degree of $\mathrm{SO}_{2}$ in $\mathrm{SCR}$ depends on several factors such as the vanadium content of the fuel and presence of other catalysts. ${ }^{53}$ In addition, the reaction rate was found to be independent of oxygen and steam concentrations, but strongly inhibited by ammonia, and slightly enhanced by $\mathrm{NO}_{\mathrm{x}}{ }^{53}$

Table $3 \mathrm{SO}_{3}$ formation at high and low oxygen concentrations

\begin{tabular}{llll}
\hline \multirow{2}{*}{ Power plant } & $\mathbf{O}_{\mathbf{2}} \mathbf{\%}$ & $\mathbf{S O}_{\mathbf{3}}(\mathbf{p p m})$ & $\mathbf{T}_{\mathbf{D P}},\left({ }^{\mathbf{o}} \mathbf{C}\right)^{1}$ \\
\hline \multirow{2}{*}{ Marchwood } & 3.0 & 20 & $130-160$ \\
& 0.5 & $2-7$ & $116-124$ \\
\hline \multirow{2}{*}{ Poole } & 4.0 & 45 & 160 \\
& $<0.6$ & 5 & 82 \\
\hline \multirow{2}{*}{ S.Denes } & 1.7 & $\mathrm{~N} / \mathrm{a}^{2}$ & $>130$ \\
& $>1.7$ & $\mathrm{~N} / \mathrm{a}$ & 130 \\
\hline \multirow{2}{*}{ Ince } & 4.5 & 18 & $\mathrm{~N} / \mathrm{a}$ \\
& 1.0 & 7 & $\mathrm{~N} / \mathrm{a}$ \\
\hline
\end{tabular}

${ }^{1} \mathrm{~T}_{\mathrm{DP}}$ - dew point; ${ }^{2} \mathrm{~N} / \mathrm{a}$ - not available.

In wet FGD, sulfuric acid in the flue gas is rapidly cooled by liquid spray. Under these conditions, the sulfuric acid vapour undergoes a shock condensation process which leads to the formation of fine sulfuric acid aerosol particles. ${ }^{54}$ According to Peterson and Jones, ${ }^{54}$ aerosol droplets have a mean diameter of 0.1 to $1.0 \mu \mathrm{m}$, which makes the droplets effective at scattering visible light and can lead to a visible plume. ${ }^{54}$ However, only a small percentage of the $\mathrm{SO}_{3}$ will end up as sulfuric acid aerosols, ${ }^{47}$ while part of it will condense on fly ash particles and be removed in the ESP or air preheaters. The quantity of fly ash, its surface area and alkalinity have a large impact on these processes. ${ }^{47}$ The quantity of $\mathrm{SO}_{3}$ removed by this mechanism is approximately $20 \%$ to $50 \%$ depending on the temperature and fly ash composition. ${ }^{47}$ On the other hand, some studies on capturing suspended particulate matter from coal-fired plants showed that the presence of $\mathrm{SO}_{3}$ in flue gas can be somewhat beneficial for effective operation of the ESP. Among such chemicals used to improve ESP performance, $\mathrm{SO}_{3}$ is often used as a conditioning agent to reduce fly ash resistivity. ${ }^{55,56}$

In summary, FGR, FGD, the catalytic effect of fly ash and other pollutants can all increase the formation of $\mathrm{SO}_{3}$ in the back end of the boiler. Relatively few studies on $\mathrm{SO}_{3}$ emissions in oxyfuel combustion are available in the literature. Thus, this paper reviews studies on $\mathrm{SO}_{3}$ emissions in conventional air- and oxy-fuel combustion environments. 


\subsection{Objectives and Scope of the Paper}

This paper aims to provide an extensive review on $\mathrm{SO}_{3}$ emissions from coal firing in conventional air- and oxy-combustion environments. The available experimental data on $\mathrm{SO}_{3}$ formation, uncatalyzed and catalyzed reactions, catalysis and the effect of combustion parameters are discussed. A brief introduction to oxy-fuel combustion, conversion of fuel sulfur to $\mathrm{SO}_{2}$, and $\mathrm{SO}_{3}$ emissions levels during the combustion are presented. Other issues such as effect of FGR, $\mathrm{SO}_{2}$ emissions, effect of temperature and residence time, the catalytic effect of fly ash and available modelling studies are also outlined. In addition, this review includes an assessment of the existing analytical methods for measuring $\mathrm{SO}_{3}$ concentrations in flue gases. Special attention is given to the experimental work conducted in laboratory-scale reactors to compare $\mathrm{SO}_{2}$ to $\mathrm{SO}_{3}$ conversion in air and oxy-fuel environments. Finally, the most recent investigations of $\mathrm{SO}_{3}$ emissions from pilot- and industrial-scale experiments are also summarized. 


\section{Oxy-Fuel Combustion Environment}

\subsection{Flue Gas Recirculation}

The amount of recycled flue gas used in the oxy-fuel systems should be sufficient to ensure flame temperatures similar to those under air-combustion conditions and comparable temperature profiles through the boiler. ${ }^{5}$ In order to reach a similar adiabatic flame temperature as that in air-combustion, $\mathrm{O}_{2}$ concentrations in the oxidant stream should be about $30 \% .^{13,57}$ Typically, this requires two-thirds of the flue gas to be recycled, and an optimum FGR ratio lies between 0.6 and $0.8 .^{4,20,58,59}$ The recycle rate is defined as the amount of FGR per mole of fuel: ${ }^{57}$

$$
\text { FGR rate }=v\left(\frac{\lambda_{\mathrm{FGR}}}{\left[\mathrm{O}_{2}\right]_{\text {Oxidant }}}-\frac{\lambda_{\mathrm{FGR}}}{\left[\mathrm{O}_{2}\right]_{\mathrm{Asu}}}\right)
$$

where $v$ is the stoichiometric coefficient of $\mathrm{O}_{2}$ for fuel used and $\left[\mathrm{O}_{2}\right]_{\text {asu }}$ and $\left[\mathrm{O}_{2}\right]_{\text {oxidant }}$ are $\mathrm{O}_{2}$ concentrations provided to the ASU and the boiler, respectively (Fig. $2^{57}$ ). Alternatively, this can be presented as the recycled flue gas ratio:

$$
\text { FGR ratio }=\frac{\text { Mol of recycled flue gas stream }}{\text { Total mol of flue gas stream of boiler outlet }} \times 100 \%
$$

Various FGR schemes were proposed by Nakayama et al. ${ }^{60}$ In their studies, the difference between dry and wet flue gas recycle is due to the presence or absence of a dehydration (condenser) unit in the system flow (see Fig. 1). The wet FGR is extracted before the flue gas condenser. ${ }^{61}$ Dry FGR can be extracted after passing through the condenser where restrictions on the moisture and $\mathrm{SO}_{2}$ content exist. ${ }^{61}$ An ASPEN-plus model developed by ANL indicates that $\mathrm{SO}_{2}$ concentration builds up with increase of FGR fraction (Table $4^{62}$ ).

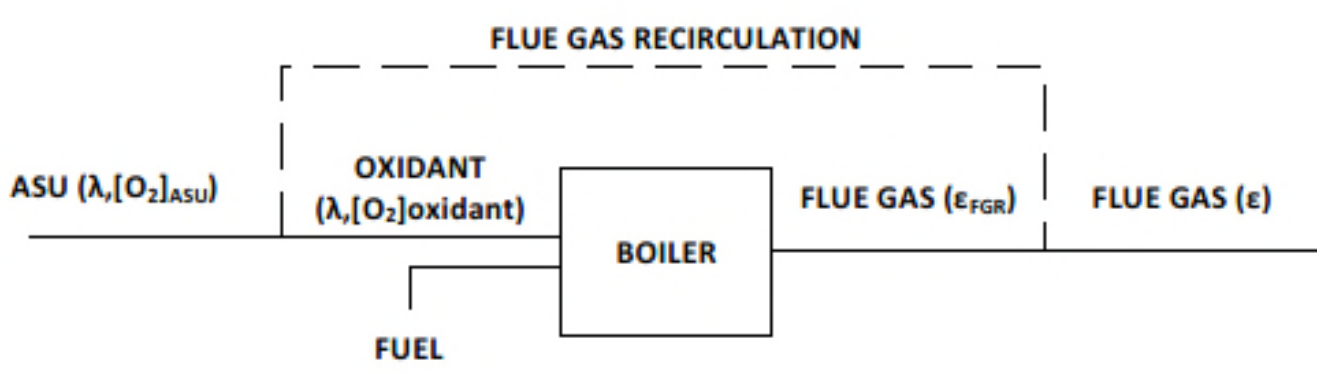

Figure 2 Simplified flue gas recycling scheme in oxy-fuel combustion 
Wet FGR can be employed after passing through the FGD unit if the $\mathrm{SO}_{2}$ concentration in the flue gas exceeds 3000 ppm. ${ }^{63}$ FGR can be separated into primary and secondary streams. This makes it advantageous to utilize low-reactivity bituminous coals. The primary stream should be scrubbed, dried and cooled to a temperature of around $250^{\circ} \mathrm{C}$ before entering the feeding mills. ${ }^{4,63}$ Primary recycling is also used for coal transportation and removing moisture. ${ }^{59,64}$ Thus, the removal of water-soluble acid gases such as $\mathrm{SO}_{3}$ and $\mathrm{HCl}$ reduce the risks of corrosion. ${ }^{57,63}$ Around $20 \%$ of the flue gas is taken as primary recycle, whereas the majority of the gas stream is extracted as the secondary stream. ${ }^{4,16}$ The recycled flue gas temperature is determined mainly by the technical parameters of the recirculation duct, fan dimensions and ESP. ${ }^{59}$ Therefore, the temperature of the FGR should be maintained between 200 and $300^{\circ} \mathrm{C} .^{59,61,65}$ Operation of the hot recirculation fan at higher flue gas temperatures can lead to higher maintenance costs. ${ }^{59}$

\section{$2.2 \mathrm{SO}_{2}$ Emissions}

In oxy-fuel combustion, the $\mathrm{SO}_{2}$ concentrations are several times higher than that in conventional air combustion. However, in terms of the specific emissions (mg/MJ), $\mathrm{SO}_{2}$ emissions are lower in the case of oxy-combustion. ${ }^{38,66}$ As discussed by Dhungel et al. ${ }^{67}$ and Fleig et al. ${ }^{68}$ lower specific emissions can be explained by higher $\mathrm{SO}_{2}$ retention by ash, and removal of $\mathrm{SO}_{2}$ by condensate in the case of dry FGR. According to Liu and Shao, ${ }^{9} \mathrm{SO}_{2}$ concentrations in oxy-fuel combustion can be 6 times higher than in an identical air-combustion unit. Higher concentration of $\mathrm{SO}_{2}$ in the flue gas occurs due to the change in volumetric flow through the combustion furnace and FGR. ${ }^{58}$ Tan et al. ${ }^{51}$ have concluded that $\mathrm{SO}_{2}$ concentrations in the furnace were 3-4 times higher than in air combustion for east US bituminous coals. Similar $\mathrm{SO}_{2}$ concentrations were noted by Fleig et al. ${ }^{39}$ in an oxy-PC unit. Relatively lower concentrations of $\mathrm{SO}_{2}$ were measured by Duan et al. ${ }^{69}$ in a $50-\mathrm{kW}$ oxy-CFB. However, the $\mathrm{SO}_{2}$ concentrations presented in this study were still higher than those seen in air-combustion. Croiset and Thambimuthu ${ }^{38}$ have also 
found that $\mathrm{SO}_{2}$ levels with RFG tests doubled when compared to once-through tests in a 210 $\mathrm{kW}$ test unit. The authors observed a decreasing trend of S-to- $\mathrm{SO}_{2}$ conversion from $91 \%$ in the air-fired case to $74 \%$ in $\mathrm{O}_{2} / \mathrm{CO}_{2}$ atmosphere. In FGR tests, this conversion was $64 \%$. According to Croiset and Thambimuthu, ${ }^{38}$ a possible reason for lower conversion was the sulfur retention by ash. Sulfur retention was also noted in experimental tests in the Chalmers University's 100 $\mathrm{kW}$ unit. ${ }^{39}$ Relatively low S-to- $\mathrm{SO}_{2}$ conversions in this case were noted in oxy-fired tests $(43 \%)$ and in air tests $(67 \%)$.

At higher temperature zones, the formation of $\mathrm{SO}_{2}$ can significantly affect flame behaviour, ${ }^{70,71}$ which was more evident in the presence of $\mathrm{CO}$ as it is reported that $\mathrm{SO}_{2}$ inhibits the $\mathrm{CO}$ burnout rate. ${ }^{72,73}$ Investigation on a bench-scale natural gas-fired $26 \mathrm{~kW}$ burner showed a clear decreasing trend in terms of $\mathrm{CO}$ emissions when 100 ppm $\mathrm{SO}_{2}$ was added under substoichiometric conditions. ${ }^{34}$ Sulfur species can also decrease the NO levels in post-flame regions. ${ }^{74-76}$ This occurs due to the catalysis of oxygen atom recombination reactions by $\mathrm{SO}_{2}{ }^{74}$ Typical mechanisms are described by Glarborg et al.: ${ }^{77}$

$$
\begin{gathered}
\mathrm{X}+\mathrm{SO}_{2}+\mathrm{M} \rightarrow \mathrm{XSO}_{2}+\mathrm{M} \\
\mathrm{Y}+\mathrm{XSO}_{2} \rightarrow \mathrm{XY}+\mathrm{SO}_{2}
\end{gathered}
$$

where $\mathrm{X}$ and $\mathrm{Y}$ may be $\mathrm{H}, \mathrm{O}$ or $\mathrm{OH}$ radicals. It is reported that under fuel-lean combustion conditions, the inhibition is mainly governed by the recombination of $\mathrm{O}$ radicals involving $\mathrm{SO}_{3},{ }^{34}$ while under fuel-rich or stoichiometric conditions the interaction of $\mathrm{SO}_{2}$ with radicals is believed to be more complex. ${ }^{78,79}$ The most important radical removal step under stoichiometric and reducing conditions is caused by the recombination of $\mathrm{SO}_{2}$ with $\mathrm{H}$ to form $\mathrm{HSO}_{2}: 78$

$$
\mathrm{SO}_{2}+\mathrm{H}+\mathrm{M} \leftrightarrow \mathrm{HSO}_{2}+\mathrm{M}
$$

The presence of $\mathrm{SO}_{2}$ also has an inhibiting effect on moist $\mathrm{CO}$ oxidation in air-firing environments. The inhibition was more pronounced at high atomic O levels; however, the presence of $\mathrm{NO}$ in the system significantly reduced the $\mathrm{SO}_{2}$ effect. ${ }^{77}$ This work has been extended recently by Giménez-Lopez et al. ${ }^{79}$ who explored this phenomenon experimentally under $\mathrm{CO}_{2}$-rich atmosphere to simulate oxy-fuel conditions. An important inhibition effect was evident in a $\mathrm{CO}_{2}$ atmosphere as compared to a $\mathrm{N}_{2}$-rich environment. This was due to the competition between $\mathrm{CO}_{2}$ and $\mathrm{O}_{2}$ for $\mathrm{H}$ radicals that reduces the formation of chain carriers via the $\mathrm{O}_{2}+\mathrm{H}$ chain branching reaction. Lower inhibition was seen when the stoichiometry shifted to oxidizing conditioning.

\section{Background for $\mathrm{SO}_{3}$ Formation in Combustion}




\subsection{Homogeneous Conversion of $\mathrm{SO}_{2}$ to $\mathrm{SO}_{3}$}

Past studies by Cullis and Mulcahy ${ }^{35}$ and Jorgensen et al. ${ }^{80}$ noted that photochemical tests on direct oxidation have been used to measure $\mathrm{SO}_{3}$. This direct homogeneous oxidation of $\mathrm{SO}_{2}$ is written as:

$$
\mathrm{SO}_{2}+\mathrm{O}_{2} \rightleftharpoons \mathrm{SO}_{3}+\mathrm{O}+161.9 \mathrm{~kJ} / \mathrm{mol}
$$

However, limited $\mathrm{SO}_{3}$ formation via reaction (6) was observed at temperatures below $900^{\circ} \mathrm{C}$. As noted by Cullis and Mulcahy, ${ }^{35}$ while direct oxidation of $\mathrm{SO}_{2}$ to $\mathrm{SO}_{3}$ is rather limited, it can be produced in much larger amounts catalytically. In addition to that, two dominant reaction pathways are recognized for homogeneous $\mathrm{SO}_{2}$ oxidation to $\mathrm{SO}_{3}$. The primary oxidation is the direct reaction of $\mathrm{SO}_{2}$ with $\mathrm{O}$ radicals that occurs in post-flame zones of the combustor:

$$
\mathrm{SO}_{2}+\mathrm{O}(+\mathrm{M}) \rightleftharpoons \mathrm{SO}_{3}(+\mathrm{M})
$$

where, $\mathrm{M}$ represents a third body. Burdett et al. ${ }^{81}$ investigated the rate of the direct oxidation reaction from 630 to $1080^{\circ} \mathrm{C}$. The authors have tested $\mathrm{SO}_{3}$ formation in $\mathrm{O}_{2} / \mathrm{N}_{2} / \mathrm{SO}_{2}$ flow and proposed the following kinetic equation to predict formation of $\mathrm{SO}_{3}:{ }^{81}$

$$
\frac{d[S O]_{3}}{d t}=\frac{k_{1}}{R T}\left[S O_{2}\right]\left[O_{2}\right]=\frac{A\left[S O_{2}\right]\left[O_{2}\right]}{R T} e^{(-B / T)}
$$

where $\mathrm{k}_{1}=\mathrm{A} \exp (-\mathrm{B} / \mathrm{T}), \mathrm{A}=2.6( \pm 1.3) * 10^{12} \mathrm{~mol}^{-1} \mathrm{~cm}^{3} \mathrm{~s}^{-1}, \mathrm{~B}=23000 \pm 1200 \mathrm{~K} .\left[\mathrm{SO}_{2}\right],\left[\mathrm{O}_{2}\right]$ and $\left[\mathrm{SO}_{3}\right]$ are partial pressures of respective gases. More detailed data on the kinetics of reactions (6) and (7) can be found elsewhere. ${ }^{82-86}$ The second pathway occurs under moist conditions, where oxidation of $\mathrm{SO}_{2}$ is enhanced in the presence of steam that increases via $\mathrm{O} / \mathrm{H}$ radical concentration:

$$
\begin{gathered}
\mathrm{SO}_{2}+\mathrm{OH}(+\mathrm{M}) \rightleftharpoons \mathrm{HOSO}_{2}(+\mathrm{M}) \\
\mathrm{HOSO}_{2}+\mathrm{O}_{2} \rightleftharpoons \mathrm{SO}_{3}+\mathrm{HO}_{2}
\end{gathered}
$$

The first route is the main source of $\mathrm{SO}_{3}$ at higher temperatures, ${ }^{34}$ while the second route contributes to $\mathrm{SO}_{3}$ formation during the cooling of flue gases. ${ }^{34,80}$ Formation of $\mathrm{SO}_{3}$ based on reactions (9) and (10) is thermodynamically favoured when exhaust gases undergo the cooling process. Production of $\mathrm{SO}_{3}$ by reaction (10) is insignificant at temperatures of $730^{\circ} \mathrm{C}$ and above. $^{87}$

The effect of $\mathrm{SO}_{2}$ concentration on $\mathrm{SO}_{3}$ formation under oxy-fuel conditions was measured by Duan et al. ${ }^{88}$ at constant reactor temperature of $600^{\circ} \mathrm{C}$ (Fig. 3). As can be seen, an increasing trend of $\mathrm{SO}_{3}$ concentration was noted with an increase of $\mathrm{SO}_{2}$ concentration in the reactor. In contrast, the conversion rate decreased with increase of $\mathrm{SO}_{2}$ concentration, which can be 
attributed to a pseudo-first-order reaction mechanism. These results were consistent with observations of Belo et al. ${ }^{89}$, Fleig et al. ${ }^{90}$ and Wang et al. ${ }^{91}$

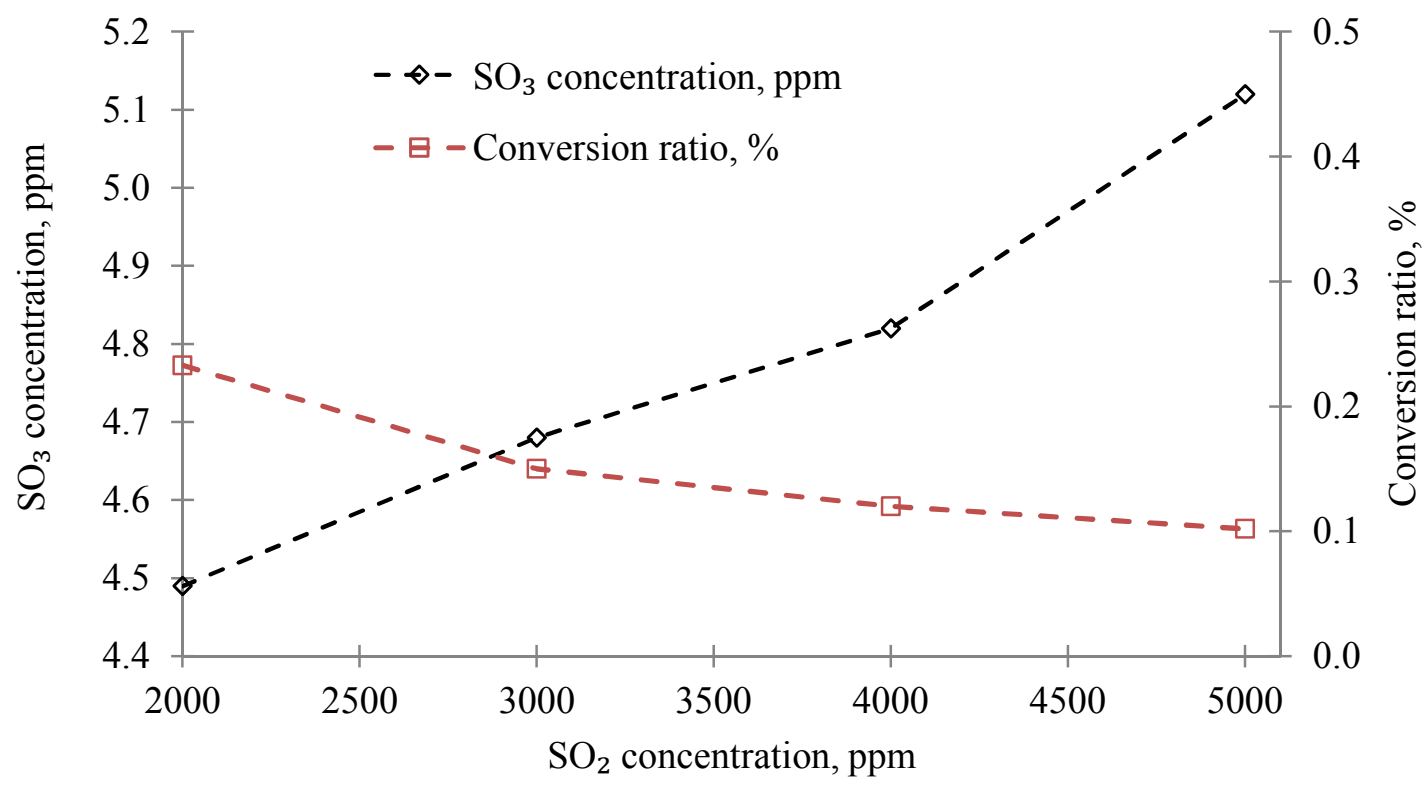

Figure 3 Effect of $\mathrm{SO}_{2}$ concentration on homogeneous $\mathrm{SO}_{3}$ formation under oxy-fuel condition. Test conditions: $6 \% \mathrm{O}_{2}, 10 \% \mathrm{H}_{2} \mathrm{O}, \mathrm{CO}_{2}-$ balance, and $600^{\circ} \mathrm{C}$ (reactor temperature)

The $\mathrm{SO}_{3} / \mathrm{SO}_{2}$ thermodynamic equilibrium was plotted using data from the online calculator developed by Colorado State University. ${ }^{92}$ Typical air- and oxy-fired flue gas compositions were selected with $\mathrm{SO}_{2}$ levels of 1000 ppm for both air and oxy flue gases, Fig. 4. $\mathrm{O}_{2}$ and $\mathrm{H}_{2} \mathrm{O}$ concentrations were changed from air- to oxy-combustion conditions, while diluted $\mathrm{N}_{2}$ was replaced by $\mathrm{CO}_{2}$ to evaluate the $\mathrm{SO}_{3} / \mathrm{SO}_{2}$ equilibrium ratios at temperatures from 400 to $950^{\circ} \mathrm{C}$. It can be seen in Fig. 4 that the formation of $\mathrm{SO}_{3}$ is thermodynamically favoured at lower temperatures, and for example, $\mathrm{SO}_{3} / \mathrm{SO}_{2}$ conversion was $100 \%$ at $400^{\circ} \mathrm{C}$ and $4.6 \%$ at $950^{\circ} \mathrm{C}$. This equilibrium curve agrees with the results presented by Belo et al ${ }^{89}$ It is also interesting to point out that air- and oxy-flue gas composition showed similar results, and only small differences are noted in the range of $500-800^{\circ} \mathrm{C}$. 


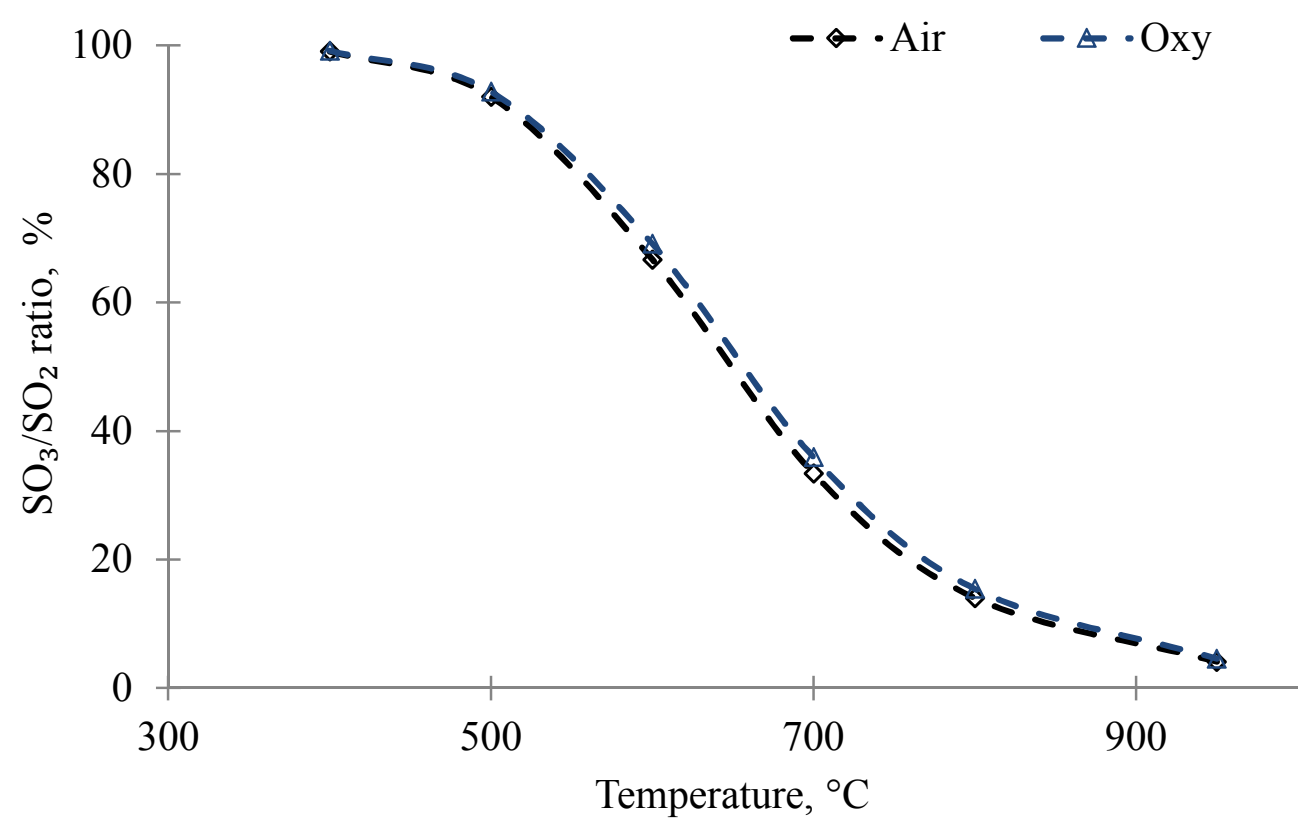

Figure 4 Thermodynamic $\mathrm{SO}_{3} / \mathrm{SO}_{2}$ equilibrium

Air-: $\mathrm{SO}_{2}-1000$ ppm, $\mathrm{O}_{2}-4 \%, \mathrm{H}_{2} \mathrm{O}-6 \%, \mathrm{CO}_{2}-15 \%, \mathrm{~N}_{2}$-balance;

Oxy-: $\mathrm{SO}_{2}-1000$ ppm, $\mathrm{O}_{2}-5 \%, \mathrm{H}_{2} \mathrm{O}-11 \%, \mathrm{CO}_{2}$-balance;

\subsection{Catalytic Conversion of $\mathrm{SO}_{2}$ to $\mathrm{SO}_{3}$}

There have been a number of investigations concerning the catalytic oxidation of $\mathrm{SO}_{2}$ to $\mathrm{SO}_{3} .{ }^{93}$ Most of these investigations indicated higher conversion of $\mathrm{SO}_{2}$ to $\mathrm{SO}_{3}$ via heterogeneous catalysis ${ }^{94-97}$ represented as:

$$
\mathrm{SO}_{2}+\mathrm{O}_{2} \stackrel{\text { Catalyst }\left(\mathrm{Fe}_{3} \mathrm{O}_{2}, \mathrm{~V}_{2} \mathrm{O}_{5}\right)}{\longrightarrow} \mathrm{SO}_{3}+\mathrm{O}
$$

Catalytic conversion of $\mathrm{SO}_{2}$ to $\mathrm{SO}_{3}$ by fly ash was investigated in a bench-scale reactor by Marier and Dibbs. ${ }^{94}$ They concluded that the conversion of $\mathrm{SO}_{2}$ to $\mathrm{SO}_{3}$ was strongly enhanced due to the iron oxide in the fly ash whereas the reverse effect was noted in the presence of unburnt carbon in the fly ash. ${ }^{94}$ Also, similar and supporting results were produced by Zhang et al. ${ }^{95}$ Extended experiments on sulfation of $\mathrm{CaO}$ and $\mathrm{MgO}$ mixed with iron oxide indicated direct relation to the catalytic conversion of $\mathrm{SO}_{2}$ to $\mathrm{SO}_{3} .{ }^{94}$ Similar work on the kinetics of $\mathrm{SO}_{3}$ adsorption by $\mathrm{CaO}$ and $\mathrm{MgO}$ was undertaken by Thibault et al. ${ }^{98}$ However, a subsequent study suggested that this might be due to the difference in grain size and porosity of the solid material. ${ }^{98}$ A modelling approach called density functional theory (DFT) was applied by Galloway et al. ${ }^{99}$ to explore binding mechanisms of $\mathrm{SO}_{3}$ to other metal compounds. Compounds such as $\mathrm{CaO}, \mathrm{MgO}, \mathrm{Na}_{2} \mathrm{O}$ and $\mathrm{K}_{2} \mathrm{O}$ that are typically found in fly ash were included 
in the model. The authors observed that $\mathrm{SO}_{3}$ binds strongly with alkali and alkaline metals, with the effect being more pronounced with alkali metals (i.e., $\mathrm{Mg}<\mathrm{Ca}<\mathrm{Na}<\mathrm{K}$ ) through the formation of a sulfate $\left(\mathrm{SO}_{4}^{2-}\right) \cdot{ }^{99}$ Cao et al. ${ }^{100}$ outlined two main interactions of fly ash with $\mathrm{SO}_{3}$ based on temperature. First, fly ash could serve as an $\mathrm{SO}_{3}$ adsorbent under low temperatures typical for the bottom section of boilers. At a temperature lower than the dew point of $\mathrm{SO}_{3}$, it converts $\mathrm{SO}_{3}$ to $\mathrm{H}_{2} \mathrm{SO}_{4}$ mist droplets in the presence of water. Subsequently, these droplets condense on fly ash surfaces. The pore structure of the fly ash, which is associated with the carbon residue, is responsible for condensation or adsorption of $\mathrm{SO}_{3}$. Chang ${ }^{101}$ investigated infrared adsorption of $\mathrm{SO}_{2}$ on $\gamma$-alumina $\left(\gamma-\mathrm{Al}_{2} \mathrm{O}_{3}\right)$ outlining two main factors, the number of hydroxyl groups and the temperature of the catalyst. Infrared spectroscopy showed that $\mathrm{SO}_{2}$ is adsorbed on $\gamma-\mathrm{Al}_{2} \mathrm{O}_{3}$ in the form of sulfite species. $\mathrm{SO}_{2}$ could also be oxidized on $\gamma-\mathrm{Al}_{2} \mathrm{O}_{3}$ to form aluminium sulfate. Vanadium catalyst contains a mixture of metal compounds of vanadium and alkali metal dispersed on a silica-based support. $\mathrm{SO}_{2}$ to $\mathrm{SO}_{3}$ oxidation by vanadium catalysts has been widely studied for SCR technology. ${ }^{97}$

\section{3 $\quad \mathrm{SO}_{3}$ Sampling Methods}

A number of different approaches for $\mathrm{SO}_{3}$ measurement have been mentioned in the literature such as: the controlled condensation method (CCM), $\mathrm{SO}_{3}$ monitor, isopropanol bottle method (IPA) and acid dew point measurements (DPM). These methods were examined by Jaworowski and Mack $^{102}$ who noted the limitations of each method in terms of reproducibility and accuracy. More recently, $\mathrm{SO}_{3}$ measurements have been revised by Fleig et al. ${ }^{103}$ Based on studies of Jaworowski and Mack ${ }^{102}$ and Fleig et al. ${ }^{103}$, a summary of each $\mathrm{SO}_{3}$ measurement method is given below.

\subsubsection{Controlled condensation method}

CCM was classified as British Standard BS 1756-4:1977 and American Standard D-3226-73T, and has been the most widely used method for $\mathrm{SO}_{3}$ measurements ${ }^{102}$. However, it should be noted that both of these standards have been withdrawn. ${ }^{104,105}$ The principle of CCM is based on cooling flue gas to a temperature between the acid dew point and water dew point. 
$\mathrm{SO}_{3}$ is condensed in the quartz filter as well as on the glass walls of the sampling train as shown in Fig. 5. A sampling time of 30 minutes is required with a flow rate of $10 \mathrm{dm}^{3} / \mathrm{min}^{106}$ After gas sampling, a known quantity of distilled deionized water is used to flush out the filter and condenser to collect the $\mathrm{H}_{2} \mathrm{SO}_{4}$, which is then determined by the titration method using $0.005 \mathrm{M}$ barium perchlorate. As shown in Fig. 5, the quartz filter is used to capture particulates before entering the condenser and impingers. The probe and quartz filter should be maintained at $260^{\circ} \mathrm{C}$ to avoid the formation of aerosol particles and condensation of sulfuric acid. ${ }^{106,107}$ The filtration of particulates from the sampling gas is crucial as the interaction of ash particles and $\mathrm{SO}_{3}$ in the sampling train can lead to both positive and negative errors. ${ }^{107}$

The glass condenser should be maintained at 80 to $90^{\circ} \mathrm{C}$. According to Maddalone et al. ${ }^{107}$ $\mathrm{CCM}$ in laboratory tests collected $95 \%$ of $\mathrm{H}_{2} \mathrm{SO}_{4}$ with a variation coefficient of $\pm 6.7 \%,{ }^{107}$ but the same authors indicated lower accuracy for the field tests. During the sampling, $\mathrm{SO}_{2}$ reacts with water and dissociates into bisulfite and sulfite ions (reactions 12 and 13). The oxidation of SO2 in reaction (14) depends on the concentration of sulfite ions in the solution, which makes the reaction strongly $\mathrm{pH}$-dependent (Fig 6):

$$
\begin{gathered}
\mathrm{SO}_{2}+\mathrm{H}_{2} \mathrm{O} \rightarrow \mathrm{H}^{+}+\mathrm{HSO}_{3}^{-} \\
\mathrm{HSO}_{3}^{-} \rightarrow \mathrm{H}^{+}+\mathrm{SO}_{3}^{2-}
\end{gathered}
$$

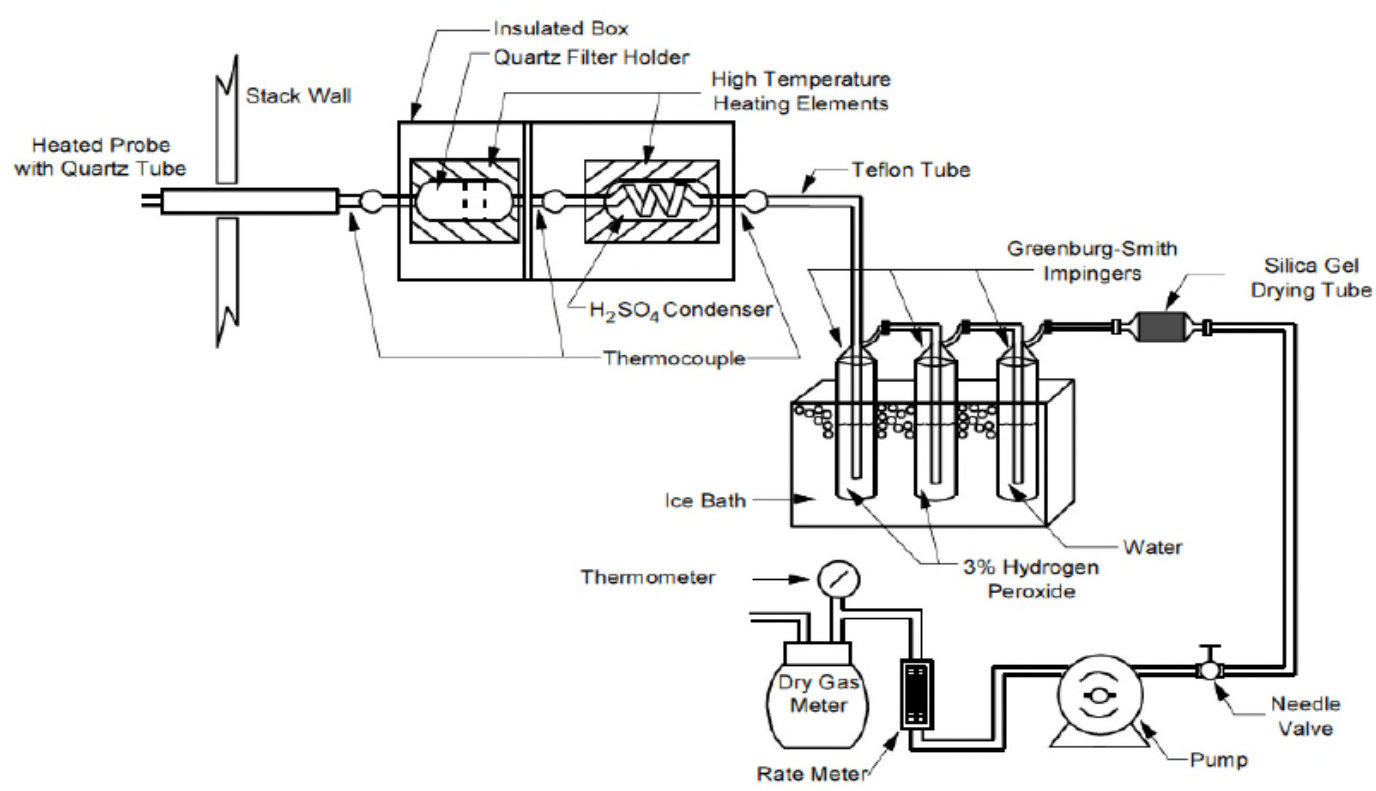

Figure 5 The modified controlled condensation method (CCM) $\mathrm{SO}_{3}$ sampling scheme. 106 


$$
\mathrm{SO}_{3}^{2-}+1 / 2 \mathrm{O}_{2} \rightarrow \mathrm{SO}_{4}^{2-}
$$

Figure 6 shows the calculated mole fraction of sulfur species as a function of $\mathrm{pH}$ at $25^{\circ} \mathrm{C}$ in aqueous solution. It can be seen that sulfites dominate in alkaline solution while bisulfite dominates in acid solutions with a $\mathrm{pH}$ range of 3-7. ${ }^{108}$ It is commonly accepted that at normal sampling conditions, the impinger solution must be slightly acidic, preventing sulfite formation and subsequent oxidation. ${ }^{108}$ Therefore, purging of impingers with air is recommended to remove $\mathrm{SO}_{2}$.

\subsubsection{Isopropanol absorption bottle method}

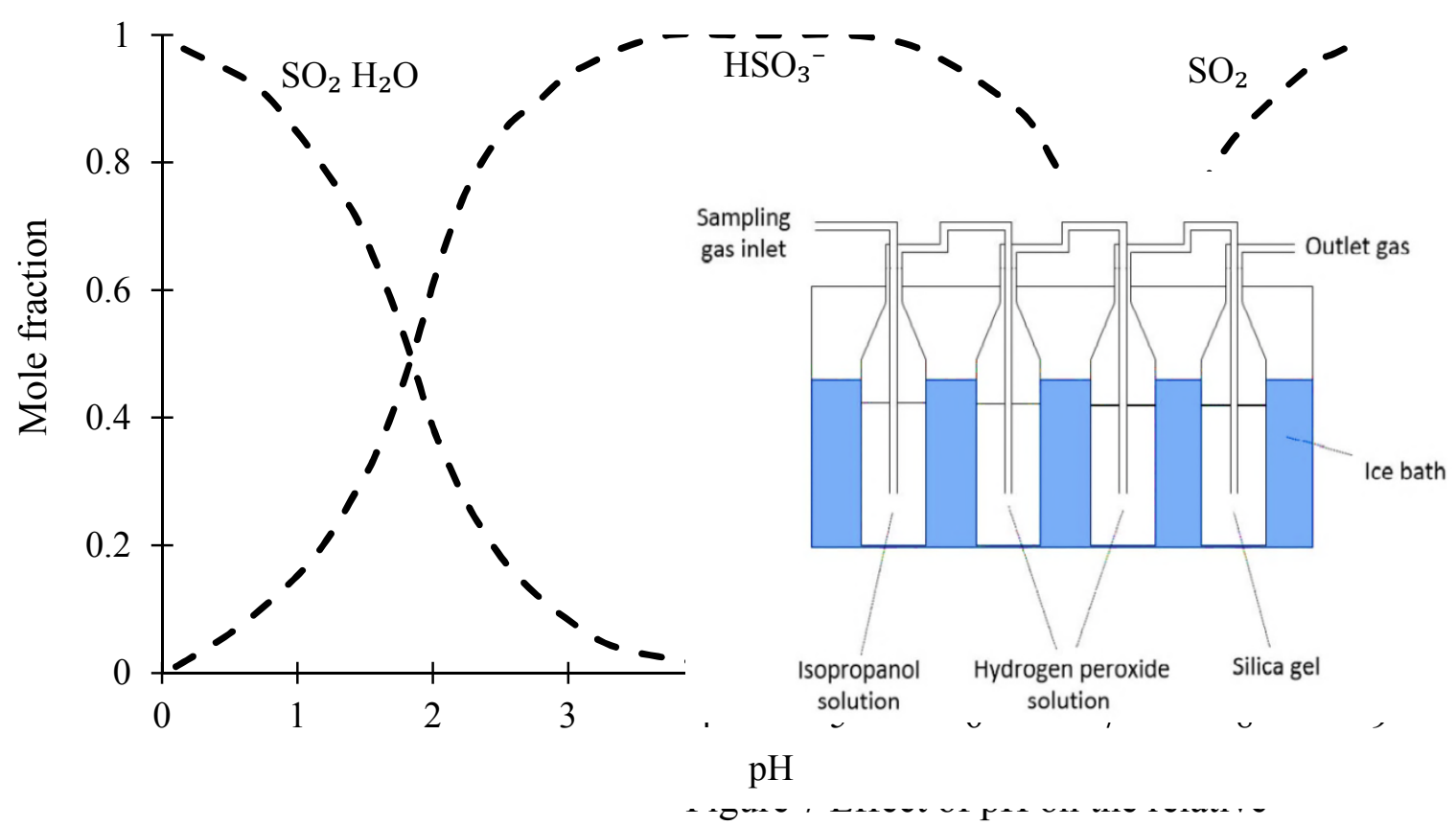

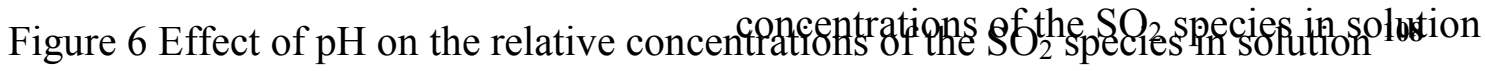

This method is based on EPA Method 8

with some modifications. A schematic illustration of the isopropanol absorption method is shown in Fig. 7. The extracted flue gas is first cooled down as in the CCM by a glass condenser and passed through four bottles, which are kept in an ice bath. The first bottle is filled with 10 $\mathrm{mL}$ of $80 \%$ isopropanol solution diluted in water, the following two bottles are filled with $3 \%$ hydrogen peroxide solution, and the fourth bottle is used to capture moisture from the gas sample with silica gel. According to Cooper, ${ }^{109}$ the most common error occuring during the 
sampling of $\mathrm{SO}_{3}$ in this method is absorption and oxidation of $\mathrm{SO}_{2}$. Similar limitations were mentioned by Fleig et al. ${ }^{103}$ where large amounts of $\mathrm{SO}_{2}$ were absorbed in the isopropanol solution and resulted in a positive bias. ${ }^{103}$

\subsubsection{Salt and glass bead methods}

The first description of the salt method was provided by Kelman in the early 1950s. ${ }^{110}$ This was later applied to industrial plant by Cooper et al. ${ }^{109}$ The advantages of this method as highlighted by the authors are: no interference from $\mathrm{SO}_{2}$ and simplicity of sampling. Flue gas containing $\mathrm{SO}_{2}$ and $\mathrm{SO}_{3}$ passes through the dry layer of $\mathrm{NaCl}$ and the sulfur trioxide reacts with $\mathrm{NaCl} .{ }^{110}$ This method was applied to detect $\mathrm{SO}_{3}$ concentration in a $100 \mathrm{~kW}$ rig at Chalmers University. ${ }^{111}$ A schematic of the salt method is shown in Fig. 8, ${ }^{111}$ where salt is fixed in the tube with glass wool. ${ }^{109,112}$ With a decrease of the gas temperature to approximately $500^{\circ} \mathrm{C}$, $\mathrm{SO}_{3}$ starts to react with water vapour to form gaseous sulfuric acid, ${ }^{103,111}$ which then reacts with $\mathrm{NaCl}$ to form $\mathrm{Na}_{2} \mathrm{SO}_{4}$ and $\mathrm{NaHSO}_{4}{ }^{111}$ The reactions occurring during the salt method are given as:

$$
\begin{gathered}
\mathrm{SO}_{3}(\mathrm{~g})+\mathrm{H}_{2} \mathrm{O}(\mathrm{g}) \rightarrow \mathrm{H}_{2} \mathrm{SO}_{4}(\mathrm{~g}) \\
\mathrm{NaCl}(\mathrm{s})+\mathrm{H}_{2} \mathrm{SO}_{4}(\mathrm{~g}) \rightarrow \mathrm{NaHSO}_{4}(\mathrm{~s})+\mathrm{HCl}(\mathrm{g}) \\
2 \mathrm{NaCl}(\mathrm{s})+\mathrm{H}_{2} \mathrm{SO}_{4}(\mathrm{~g}) \rightarrow \mathrm{Na}_{2} \mathrm{SO}_{4}(\mathrm{~s})+2 \mathrm{HCl}(\mathrm{g}) \\
\mathrm{NaHSO}_{4}(\mathrm{~s})+\mathrm{NaCl}(\mathrm{s}) \rightarrow \mathrm{Na}_{2} \mathrm{SO}_{4}(\mathrm{~s})+\mathrm{HCl}(\mathrm{g}) \\
4 \mathrm{NaCl}(\mathrm{s})+2 \mathrm{SO}_{2}(\mathrm{~g})+2 \mathrm{H}_{2} \mathrm{O}(\mathrm{g})+\mathrm{O}_{2}(\mathrm{~g}) \rightarrow 2 \mathrm{Na}_{2} \mathrm{SO}_{4}(\mathrm{~s})+4 \mathrm{HCl}(\mathrm{g})
\end{gathered}
$$

The last reaction is undesirable as it leads to a positive bias. ${ }^{103}$ Sulfation of $\mathrm{NaCl}$ is a slow reaction and mainly depends on temperature and $\mathrm{SO}_{2}$ concentration. Vainio et al. ${ }^{111}$ have extended this method by testing

other salts $\left(\mathrm{KCl}, \mathrm{K}_{2} \mathrm{CO}_{3}\right.$, and $\mathrm{CaCl}_{2}$ ) along with $\mathrm{NaCl}$. Tests with $\mathrm{NaCl}$ and $\mathrm{KCl}$ showed comparable results to the CCM. Less convincing results were observed with $\mathrm{K}_{2} \mathrm{CO}_{3}$ and $\mathrm{CaCl}_{2}{ }^{111}$

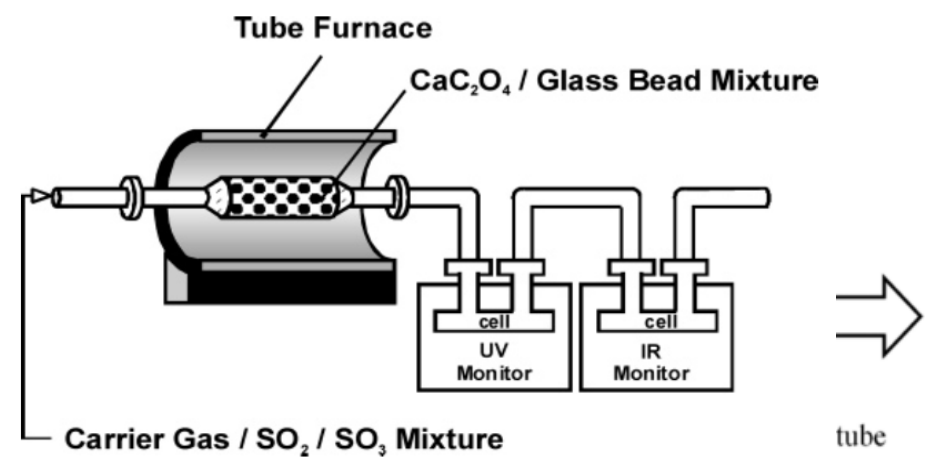

\subsubsection{Indirect measurements of $\mathrm{SO}_{3}$}

Figure 9 Firrangement for $\mathrm{SO}_{3}$ measurements by $\mathrm{CaC}_{2} \mathrm{O}_{4}{ }^{113}$ 
Ibanez et al. ${ }^{113}$ described an indirect measurement method employing calcium oxalate, which is based on the next reaction:

$$
\mathrm{SO}_{3}+\mathrm{CaC}_{2} \mathrm{O}_{4} \rightarrow \mathrm{CaSO}_{4}+\mathrm{CO}_{2}+\mathrm{CO}
$$

This method is sensitive to temperature control and the reaction vessel should be maintained at $325^{\circ} \mathrm{C}$. A mixture of gas passes through a plug of prepared $\mathrm{CaC}_{2} \mathrm{O}_{4}$ then through two optical cells in series (see Fig 9). The $\mathrm{SO}_{2}$ content in the sample gas is monitored by means of UV spectrometry, while the $\mathrm{SO}_{3}$ concentration is quantified indirectly measuring $\mathrm{CO}_{2}$ in the second cell by IR spectrometry. The authors underlined that the preparation of reagent and calibration should be done very carefully to produce reliable results. A similar approach has been developed by Fateev and Clauson ${ }^{114}$, but they presented only preliminary results.

Continuous $\mathrm{SO}_{3}$ measurement by Fourier transform infrared (FTIR) and differential optical absorption spectroscopy (DOAS) was described by EPRI. ${ }^{115}$ Subsequently a modified crossduct probe design was developed to improve $\mathrm{SO}_{3}$ measurements by FTIR. The result of continuous measurements for 3 days with FTIR was in good agreement with that determined by the CCM method. However, variation of $\mathrm{SO}_{3}$ across probes was $10 \% .{ }^{31}$ An indirect test of $\mathrm{SO}_{3}$ with FTIR has also been attempted by measuring $\mathrm{HCl}$ from reaction of $\mathrm{NaCl}$ with $\mathrm{H}_{2} \mathrm{SO}_{4}$. In this case, the exit gas temperature should be kept between $200-400^{\circ} \mathrm{C}$. However, at $200^{\circ} \mathrm{C}$, only about one-half the $\mathrm{SO}_{3}$ was converted to $\mathrm{HCl} .{ }^{111}$ Chamberlain et al. ${ }^{116}$ have also attempted to measure $\mathrm{SO}_{3}$ concentrations with FTIR and the uncertainty of measurement was $\pm 20 \mathrm{ppm}$. Given this range of uncertainty, the authors could not see a difference in $\mathrm{SO}_{3}$ concentrations between air and oxy-fuel combustion. Therefore, both of these indirect methods still need to be improved before they can be reliably used in practice. Roy et al. ${ }^{117}$ carried out such measurements for laboratory-scale oxy-fuel experiments, but they did not comment on the consistency of measurements and the effect of reaction conditions.

\subsubsection{Pentol $\mathrm{SO}_{3}$ monitor}

This device was previously called the Severn Science reactive gas analyzer, ${ }^{118}$ and Jackson et al. ${ }^{118}$ were the first to describe this method and device. The principle of this instrument is that $\mathrm{SO}_{3}$ and $\mathrm{H}_{2} \mathrm{SO}_{4}$ in the gas sample are absorbed as $\mathrm{SO}_{4}^{2-}$ in an aqueous solution of isopropanol. During the sampling, the solution is continuously passed through a bed of barium chloranilate where the following reaction occurs: 


$$
\mathrm{SO}_{4}^{2-}+\mathrm{BaC}_{6} \mathrm{O}_{4} \mathrm{Cl}_{2}+\mathrm{H}^{+} \rightarrow \mathrm{BaSO}_{4}+\mathrm{HC}_{6} \mathrm{O}_{4} \mathrm{Cl}_{2}^{-}
$$

The released acid chloranilate ions absorb light at $535 \mathrm{~nm}$, producing a purple-coloured solution, and the concentration of this chemical is continuously measured by a flow photometer. The amount of sulfate in the solution is proportional to the $\mathrm{SO} 3$ concentration entering the analyzer ${ }^{119}$. According to Dennis and Hayhurst ${ }^{120}$, this instrument was slow to achieve steady-state performance and required moisture in the fluidization gases to ensure reliable readings. Cooper. ${ }^{109}$ applied the Severn Science gas analyzer at the Orimulsion power plant, where the average results were $25 \%$ higher than those determined by the CCM approach. One reason for higher concentrations could be absorption of $\mathrm{SO}_{2}$ in the isopropanol and partial oxidation of $\mathrm{SO}_{3}^{2-}$ to $\mathrm{SO}_{4}^{2-}$. This was confirmed by peaks for both $\mathrm{SO}_{3}^{2-}$ and $\mathrm{SO}_{4}^{2-}$ in the ion chromatograph analysis. ${ }^{109}$ The study by Fleig et al. ${ }^{103}$ supports the reliability of this method, especially over longer continuous sampling periods. However, the average readings were still $20 \%$ lower compared to those from CCM. ${ }^{103}$ Therefore, it is clear from the discussion above that there are still many issues related to accuracy of $\mathrm{SO}_{3}$ measurements that need to be addressed.

\subsubsection{Acid dew point measurements}

The measurement of sulfuric acid dew point (ADP) temperature is one of the conventional ways to estimate the amount of $\mathrm{SO}_{3}$ when $\mathrm{H}_{2} \mathrm{O}$ concentration in the flue gas is known. Taylor ${ }^{123}$ concluded that the condensation of sulfuric acid is a function of the surface temperature of the

Table 5 Sulfuric acid dew-point (ADP) correlations

\begin{tabular}{ll}
\hline Authors & Correlations \\
\hline $\begin{array}{l}\text { Verhoff and } \\
\text { Banchero }{ }^{121}\end{array}$ & $\frac{1}{T_{\text {Dew }}+273.15}=0.002276-0.00002943 \ln p_{\mathrm{H}_{2} \mathrm{O}}-0.0000858 \ln p_{\mathrm{H}_{2} \mathrm{SO}_{4}}$ \\
& $+0.00000620\left(\ln p_{\mathrm{H}_{2} \mathrm{SO}_{4}}\right)\left(\ln p_{\mathrm{H}_{2} \mathrm{O}}\right)$ \\
Okkes $^{122}$ & $T_{\mathrm{Dew}}=203.25+27.6 \log p_{\mathrm{H}_{2} \mathrm{O}}+10.86 \log p_{\mathrm{SO}_{3}}+1.06\left(\log p_{\mathrm{SO}_{3}}+8\right)^{2.19}$ \\
ZareNezhad $^{122}$ & $T_{\mathrm{Dew}}=150+11.664 \ln \left(p_{\mathrm{SO}_{3}}\right)+8.1328 \ln \left(p_{\mathrm{H}_{2} \mathrm{O}}\right)-0.383226 \ln \left(p_{\mathrm{SO}_{3}}\right) \ln \left(p_{\mathrm{H}_{2} \mathrm{O}}\right)$ \\
\hline
\end{tabular}

sampling tube and the water vapour content in the flue gases. Measurements of ADP were conducted using a cooled electrical conductivity probe to determine the temperature where 
condensation occurs. ${ }^{124}$ The probe has two electrodes and a thermocouple. The ADP is identified by a sudden increase in the conductivity between electrodes on the surfaces due to the condensed liquid sulfuric acid solution. Currently, advanced portable devices (Lancom 200) are available to measure ADP of the flue gases. ${ }^{124}$ The ADP changes with the moisture content of the flue gases, which is particularly important for an oxy-fuel combustion environment. Available correlations to estimate the ADP temperature are illustrated in Table 5. According to Verhoff and Banchero, ${ }^{121}$ two methods have been developed to define the vapour and liquid equilibrium for aqueous sulfuric acid solutions. The first method was determined by measuring the vapour-liquid compositions and temperature at equilibrium. The second method takes into account liquid and pure components to estimate the equilibrium vapour and liquid compositions via thermodynamics. Based on these two methods, Verhoff and Banchero ${ }^{121}$ have proposed a correlation to predict the dew point of sulfuric acid. More recently, ZareNezhad ${ }^{122}$ has proposed a new correlation to predict flue gas sulfuric acid. Based on these correlations, Stanger et al. ${ }^{29}$ compared both correlations for composition of flue gas derived from oxy-fuel combustion. The authors concluded that the Verhoff and Banchero method over-estimate experimental dew points at low $\mathrm{SO}_{3}$ concentrations and high moisture content. The Okkes correlation has been found to be better suited for flue gases with moisture content higher than $25 \% .^{29}$

\section{Influence of Oxy-fuel Parameters on $\mathrm{SO}_{3}$}

\subsection{Effect of $\mathrm{O}_{2} / \mathrm{CO}_{2}$ Environment}

$\mathrm{SO}_{3}$ concentrations in an oxy-fuel environment are several times higher than in a typical aircombustion environment. ${ }^{38,125}$ Higher $\mathrm{SO}_{3}$ and $\mathrm{SO}_{2}$ concentrations along with wet FGR will result in a higher ADP temperature, which leads to corrosion issues. At the bench-scale level, the formation of $\mathrm{SO}_{3}$ in an $\mathrm{O}_{2} / \mathrm{CO}_{2}$ environment was investigated by several researchers, for example by Fleig et al. ${ }^{90,126}$ Sporl et al. ${ }^{127}$ Belo et al. ${ }^{128}$ and more recently by Duan et al. ${ }^{88}$ According to these authors, elevated $\mathrm{O}_{2}$ concentration in oxy-fuel combustion enhances $\mathrm{SO}_{3}$ formation. Belo et al. ${ }^{89}$ have observed that $\mathrm{O}_{2}$ concentrations of $3 \%, 5 \%$ and $10 \%$ resulted in $\mathrm{SO}_{2}$ oxidation of $3-10 \%$. These results agree well with the equilibrium calculation of Zheng and Furimsky. ${ }^{129}$ Fleig et al. ${ }^{90,126}$ concluded that replacing $\mathrm{N}_{2}$ with $\mathrm{CO}_{2}$ had a strong effect at higher temperatures. This might be due to higher effectiveness of third-body collisions, the effect of which is smaller at lower temperatures. ${ }^{88}$ Fleig et al. ${ }^{90}$ also noted $30 \%$ higher $\mathrm{SO}_{3}$ concentrations when the $\mathrm{CO}_{2}$ environment was compared to that of $\mathrm{N}_{2}$. A sensitivity analysis 
at $1027^{\circ} \mathrm{C}$ indicated that $\mathrm{SO}_{3}$ formation was enhanced due to the increase of concentrations of radicals due to the third-body $(\mathrm{M})$ reactions:

$$
\begin{gathered}
\mathrm{HO}_{2}(+\mathrm{M}) \rightleftharpoons \mathrm{H}+\mathrm{O}_{2}(+\mathrm{M}) \\
\mathrm{H}+\mathrm{O}_{2} \rightleftharpoons \mathrm{O}+\mathrm{OH}
\end{gathered}
$$

The formation of $\mathrm{H}$ radicals is enhanced via reaction (22), and they then react with $\mathrm{O}_{2}$ to form $\mathrm{OH}$ radicals according reaction (23). In addition, FGR increases the level of impurities such as $\mathrm{NOx}, \mathrm{SO}_{2}$ and $\mathrm{CO}$ that are believed to enhance the $\mathrm{SO}_{3}$ formation to some extent as discussed below.

\subsubsection{Effect of $\mathrm{NO}_{\mathrm{x}}$ emissions}

It has been noted that $\mathrm{NO}_{\mathrm{x}}$ may have a catalytic effect on $\mathrm{SO}_{2} / \mathrm{SO}_{3}$ conversion even at low temperatures. ${ }^{35,130,131}$ This effect can occur through either a direct or an indirect route by interaction with the radical pool composition. ${ }^{34}$ At low temperatures $\mathrm{SO}_{2}$ may react directly with $\mathrm{NO}_{2}$ to produce $\mathrm{SO}_{3}:{ }^{130}$

$$
\begin{gathered}
2 \mathrm{NO}+\mathrm{O}_{2} \rightleftharpoons 2 \mathrm{NO}_{2} \\
\mathrm{NO}_{2}+\mathrm{SO}_{2} \rightleftharpoons \mathrm{NO}+\mathrm{SO}_{3}
\end{gathered}
$$

According to Wendth and Sternling ${ }^{131}$ the $\mathrm{SO}_{2}$ oxidation was second order in respect to $\mathrm{NO}$ and had low activation energy at high concentrations of NO, and the reaction is of the first order in respect to NO with high activation energy at low concentrations of NO. At low concentrations of $\mathrm{NO}$, reaction (24) is slow, and $\mathrm{SO}_{2}$ oxidation can occur via the following route: ${ }^{131}$

$$
\begin{gathered}
\mathrm{NO}+\mathrm{O}_{2} \rightleftharpoons \mathrm{NO}_{3} \\
\mathrm{NO}_{3}+\mathrm{SO}_{2} \rightleftharpoons \mathrm{SO}_{3}+\mathrm{NO}_{2}
\end{gathered}
$$

In addition, at low temperatures $\mathrm{NO}$ may indirectly increase $\mathrm{SO}_{3}$ formation by converting $\mathrm{HO}_{2}$ in reactions (9) and (10) back to $\mathrm{OH}$ radicals: ${ }^{34}$

$$
\mathrm{NO}+\mathrm{HO}_{2} \rightleftharpoons \mathrm{NO}_{2}+\mathrm{OH}
$$

This was noted by Fleig et al. ${ }^{126}$ when a small amount of NO (100 ppm) favoured the formation of $\mathrm{SO}_{3}$. The authors also noted an increase in $\mathrm{SO}_{3}$ concentrations when more $\mathrm{OH}$ radicals were available through reaction (28) at temperatures higher than $1027^{\circ} \mathrm{C}$ and $\mathrm{SO}_{3}$ was formed through reactions (9) and (10). ${ }^{126}$ They also reported a notable increase in $\mathrm{SO}_{3}$ formation in the presence of 50 ppm NO in an oxy-fuel environment.

$$
\mathrm{H}+\mathrm{O}_{2}(+\mathrm{M}) \rightleftharpoons \mathrm{HO}_{2}(+\mathrm{M})
$$

According to Glarborg et al., ${ }^{34}$ the rate of reaction (29) is higher in a $\mathrm{CO}_{2}$ environment than in $\mathrm{N}_{2}$ which favours $\mathrm{HO}_{2}$ formation. Excess formation of $\mathrm{OH}$ via reaction (28) promotes 
secondary formation of $\mathrm{SO}_{3}$ via reactions. This effect was more pronounced in a $\mathrm{CO}_{2}$ environment. ${ }^{126}$ In the extended numerical work by Fleig et al. ${ }^{126}$ a higher value for the thirdbody coefficient of 2.5 for $\mathrm{CO}_{2}$ (instead of 1.0) resulted in negligible (2\%) reduction of $\mathrm{SO}_{3}$, which is still higher than that in the air-firing case. Thus, the impact of $\mathrm{SO}_{2}$ oxidation by nitrogen oxide during cooling is likely to be small and the effect of NO can be assumed to be negligible in oxy-fuel combustion. ${ }^{131}$

\subsubsection{Effect of carbon monoxide}

Previous studies showed that the CO concentration in oxy-fuel is higher than that in air combustion processes due to relatively higher flame temperatures, ${ }^{129,132,133}$ and most CO is formed in or near the burner region. ${ }^{133,134}$ In high-temperature zones in a $\mathrm{CO}_{2}$-rich environment, the thermal dissociation of $\mathrm{CO}_{2}$ can also contribute to higher $\mathrm{CO}$ concentrations: $:^{134}$

$$
\mathrm{CO}_{2}(+\mathrm{M}) \rightleftharpoons \mathrm{CO}+\mathrm{O}(+\mathrm{M})
$$

However, this reaction occurs only at temperatures significantly higher than $930^{\circ} \mathrm{C} \cdot{ }^{134} \mathrm{CO}_{2}$ can compete with $\mathrm{O}_{2}$ for atomic hydrogen, and will lead to the formation of $\mathrm{CO}:{ }^{132,134}$

$$
\mathrm{CO}_{2}+\mathrm{H} \rightleftharpoons \mathrm{CO}+\mathrm{OH}
$$

Simultaneously, during the formation of CO in the flame zone, the recombination of $\mathrm{CO}$ with $\mathrm{OH}$ can take place ${ }^{85}$ and this will increase the formation of $\mathrm{H}$ radicals due to reverse reaction (31). This will compete with reaction (9) for $\mathrm{OH}$ radicals and that reduces the formation of $\mathrm{SO}_{3}$ as noted in the experiments of Wang et al. ${ }^{91}$ and Fleig et al. ${ }^{90}$ It is worth mentioning that an early experiment from the staged combustion of a $\mathrm{CH}_{4} / \mathrm{H}_{2} \mathrm{~S} /$ air mixture showed enhanced $\mathrm{SO}_{3}$ formation in the presence of $1100 \mathrm{ppm}$ of $\mathrm{CO} .{ }^{85}$ The maximum $\mathrm{SO}_{2}$ oxidation took place at flame temperatures between 1300 and $1650^{\circ} \mathrm{C}$ for single and staged combustion. A narrow temperature range of 1100 to $1300^{\circ} \mathrm{C}$ was observed for the test where the secondary air supply was delayed for $30 \mathrm{~ms}$. These authors postulated that the maximum $\mathrm{SO}_{3}$ formation was only a transient phenomenon. The $\mathrm{SO}_{3}$ concentration changed as the reactions continued in the downstream gas. In addition, there was no enhancement of $\mathrm{SO}_{3}$ for residence time beyond 90 ms. The authors believe that enhancement of $\mathrm{SO}_{3}$ formation was dependent on the air/fuel ratio of each combustion stage and the delay interval between the first and second stage ${ }^{85}$. These results were also supported by Bayless et al. ${ }^{135}$ In the experimental work of Fleig et al. ${ }^{90}$ addition of 1000 ppm $\mathrm{CO}$ into the system increased the $\mathrm{SO}_{3}$ formation significantly compared to the test without $\mathrm{CO}$ addition. The measured $\mathrm{SO}_{3}$ concentrations were three times higher at a temperature of $927^{\circ} \mathrm{C}$ with $3 \% \mathrm{O}_{2}$. However, a further increase of $\mathrm{CO}$ to $3000 \mathrm{ppm}$ showed 
only a small difference compared to the 1000 ppm CO addition. In summary, it appears that the maximum $\mathrm{SO}_{3}$ formation in the presence of $\mathrm{CO}$ takes place at temperatures between 827 and $1027^{\circ} \mathrm{C}$. Lower formation of $\mathrm{SO}_{3}$ at temperatures higher than $1127^{\circ} \mathrm{C}$ was noted by Fleig et al. ${ }^{90}$ This indicates that $\mathrm{SO}_{3}$ formation is significantly affected by the temperature where burnout of the fuel takes place. In general, these results agree well with the studies of Merryman and Levy. ${ }^{85}$

\subsubsection{Effect of steam}

The wet FGR in oxy-fuel combustion can increase the steam level to $25-35 \%$ in the combustion system. ${ }^{136}$ This increase may enhance secondary formation of $\mathrm{SO}_{3}$ via $\mathrm{HOSO}_{2}$ reactions (9) and (10). In the tests by Fleig et al. ${ }^{90}$ a more pronounced effect of steam on $\mathrm{SO}_{3}$ formation was noticed between 1130 and $1200^{\circ} \mathrm{C}$. In the presence of steam $\mathrm{OH}$ radicals can be formed by the reaction of $\mathrm{H}_{2} \mathrm{O}$ with $\mathrm{O}$ radicals: ${ }^{84}$

$$
\mathrm{H}_{2} \mathrm{O}+\mathrm{O} \rightleftharpoons \mathrm{OH}+\mathrm{OH}
$$

and also by the decomposition of steam as noted by Wine et al.: ${ }^{137}$

$$
\mathrm{H}_{2} \mathrm{O} \rightleftharpoons \mathrm{OH}+\mathrm{H}
$$

Decomposition of $\mathrm{HO}_{2}$ and $\mathrm{OH}$ release through reactions (22) and (23) shifts reaction (34) to the left and enhances $\mathrm{SO}_{3}$ formation. In addition, the third-body efficiency of $\mathrm{H}_{2} \mathrm{O}$ is higher than that of $\mathrm{CO}_{2}$ and $\mathrm{N}_{2}{ }^{90}$ Fleig et al. ${ }^{90}$ have pointed out that an increase of $\mathrm{H}_{2} \mathrm{O}$ from $0.1 \%$ to $1.1 \%$ and $8.7 \%$ result in higher $\mathrm{SO}_{3}$ concentrations at temperatures between 927 and $1127^{\circ} \mathrm{C}$. At $1174^{\circ} \mathrm{C}$ and $8.7 \% \mathrm{H}_{2} \mathrm{O}, \mathrm{SO}_{3}$ concentration reached $23 \mathrm{ppm}$. However, in the presence of combustibles, the inhibiting effect of steam in $\mathrm{SO}_{3}$ formation was noted. ${ }^{90}$ This observation agrees well with the previous conclusion of Glarborg et al. ${ }^{77}$ A less pronounced effect of $\mathrm{H}_{2} \mathrm{O}$ on $\mathrm{SO}_{3}$ was noted by Belo et al. ${ }^{128}$ The effect of steam was also studied by Duan et al. ${ }^{88}$ at $600^{\circ} \mathrm{C}$, who identified an increase of $\mathrm{SO}_{3}$ concentration from $3.7 \mathrm{ppm}$ to $7.1 \mathrm{ppm}$ when steam increased from $5 \%$ to $15 \%$.

In contrast to these studies, a decreasing $\mathrm{SO}_{3}$ formation was observed in homogeneous tests of Wang et al. ${ }^{91}$ In this work, higher concentrations of steam (15 to 35\%) were employed to simulate wet FGR. The authors claimed that less pronounced formation of $\mathrm{SO}_{3}$ was due to the inhibiting effect of steam. In oxy-fuel combustion tests, a further increase of $\mathrm{H}_{2} \mathrm{O}$ to $35 \%$ showed a stronger inhibiting effect on $\mathrm{SO}_{3}$, which is consistent with the result from Fleig et al. ${ }^{90}$

According to Hindyarti et al. ${ }^{138}$ and Glarborg et al. ${ }^{77}$, major consumption of $\mathrm{SO}_{3}$ in combustion could be due to reactions (34) to (36). 


$$
\begin{gathered}
\mathrm{SO}_{3}+\mathrm{H} \rightleftharpoons \mathrm{SO}_{2}+\mathrm{OH} \\
\mathrm{SO}_{3}+\mathrm{O} \rightleftharpoons \mathrm{SO}_{2}+\mathrm{O}_{2} \\
\mathrm{SO}_{3}+\mathrm{OH} \rightleftharpoons \mathrm{SO}_{2}+\mathrm{OH}_{2}
\end{gathered}
$$

In addition, in their experiments $\mathrm{H}_{2} \mathrm{O}$ concentrations were higher than $\mathrm{SO}_{2}$ concentrations, and under such conditions, steam was more likely to compete for $\mathrm{O}$ radicals. As a result, $\mathrm{O}$ radicals formed $\mathrm{OH}$ radicals resulting in lower $\mathrm{SO}_{3}$ formation through reaction (7).

\subsection{Temperature and Residence Time}

Flint and Lindsay ${ }^{139}$ and Burdett et al. ${ }^{81}$ carried out pioneering investigations on oxidation of $\mathrm{SO}_{2}$ in quartz tube reactors in air environment. In both tests an increasing trend in homogeneous $\mathrm{SO}_{3}$ formation with temperature and residence time was noted. Increase of $\mathrm{SO}_{3}$ formation with increase of furnace and flame temperatures was also investigated earlier by Crumley and Fletcher ${ }^{140}$ (Table 6). Later, a similar approach in an $\mathrm{O}_{2} / \mathrm{N}_{2}$ environment was explored by Belo et al. ${ }^{89}$ As shown in Table 6 , the homogeneous conversion ratio from $0.04 \%$ to $0.77 \%$ was achieved by increasing temperature from 400 to $1000^{\circ} \mathrm{C}$. In their test, a conversion increase was noted when the reaction temperature went above $700^{\circ} \mathrm{C}$, but temperatures above $900^{\circ} \mathrm{C}$ were required for significant conversion for the tests with a residence time of $1 \mathrm{~s} .{ }^{89}$ For that residence time, the maximum conversion was $0.36 \%$, which agrees well with the previous results of Flint and Lindsay ${ }^{139}$ and Burdett et al. ${ }^{81}$ The $\mathrm{SO}_{2}$ to $\mathrm{SO}_{3}$ conversion vs temperature is illustrated in Fig 10. More results on homogeneous $\mathrm{SO}_{3}$ formation in quartz tube reactors can be found in Table 6 . 
The effect of temperature on homogeneous $\mathrm{SO}_{3}$ formation under different environments was also studied by Duan et al. ${ }^{88}$ In their studies $\mathrm{SO}_{3}$ concentration increased with temperature even at the lower temperature range $\left(400\right.$ to $\left.700^{\circ} \mathrm{C}\right){ }^{88}$ The reason for $\mathrm{SO}_{3}$ formation in this experiment could be the high $\mathrm{SO}_{2}$ concentration (3000 ppm) employed. It is known that at lower temperatures $\mathrm{SO}_{3}$ is formed by oxidation of molecular oxygen via reactions (9) and (10) and that $\mathrm{SO}_{3}$ formation is thermodynamically favoured with decreasing temperature. Overall, the observations of Duan et al. ${ }^{88}$ agree with the findings of Belo et al. ${ }^{128}$ Fleig et al. ${ }^{90}$ have carried out experiments on homogeneous $\mathrm{SO}_{3}$ formation over a much wider temperature range (Table 6), and they concluded that less than $1 \mathrm{ppm} \mathrm{SO}_{3}$ was formed at temperatures below $727^{\circ} \mathrm{C}$. The lower level of $\mathrm{SO}_{3}$ seen in their work was due to the short residence time, as noted by Flint and Lindsay ${ }^{139}$ and the low level of $\mathrm{H}_{2} \mathrm{O}(1.11 \%)$.

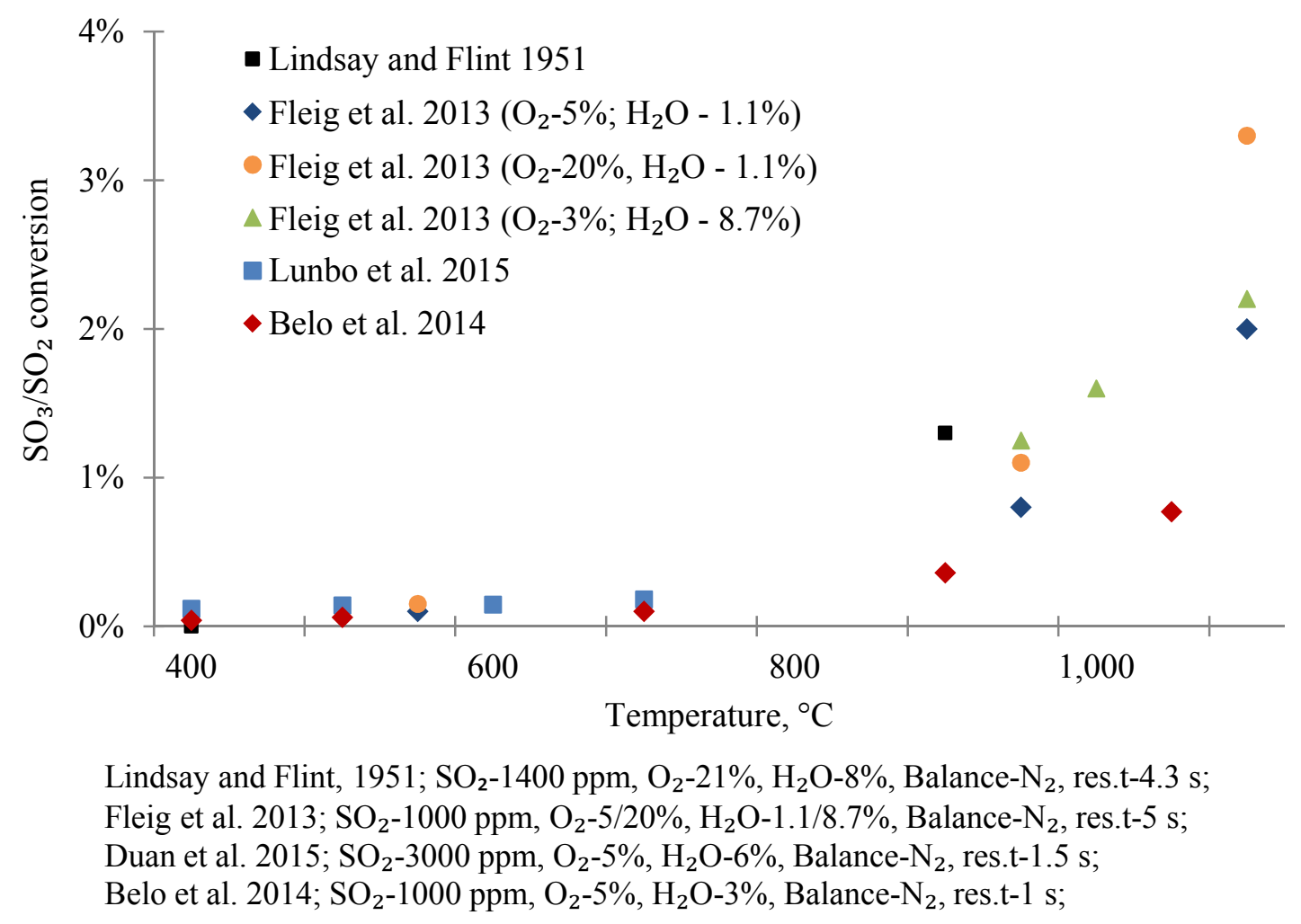

Figure 10 Effect of reactor temperature on homogeneous formation of $\mathrm{SO}_{3}$ 
Table 6 Homogeneous $\mathrm{SO}_{3}$ formation in quartz tube flow reactors

\begin{tabular}{|c|c|c|c|c|c|c|c|}
\hline Reference & $\begin{array}{l}\text { Reactor Size } \\
\qquad(\mathrm{d} \times \mathbf{l}) \\
\mathbf{m m}\end{array}$ & $\begin{array}{l}\text { Temperature } \\
\left({ }^{\circ} \mathrm{C}\right)\end{array}$ & Inlet gas composition & $\begin{array}{l}\text { Flow rate } \\
\text { (L/min) }\end{array}$ & $\begin{array}{l}\text { Residence } \\
\text { time } \\
\text { (s) }\end{array}$ & $\begin{array}{c}\text { Maximum } \\
\text { temperature } \\
\left({ }^{\circ} \mathrm{C}\right)\end{array}$ & $\begin{array}{c}\mathrm{SO}_{3} /\left(\mathrm{SO}_{2}+\mathrm{SO}_{3}\right) \\
(\%)\end{array}$ \\
\hline Barret et al. ${ }^{141}$ & $25.4 \times 610$ & $1030-1530$ & Air $+0.7 \% \mathrm{SO}_{2}$ & 3.4 & $5.5-5.7$ & 1530 & 0.2 \\
\hline Flint and Lindsay ${ }^{139}$ & $14 \times 1829$ & $500-900$ & $\begin{array}{l}\text { Air }\left(+\mathrm{H}_{2} \mathrm{O}-8 \%\right), \\
\mathrm{SO}_{2}(1400 \mathrm{ppm})\end{array}$ & $1.7-8.5$ & $0.9-9.6$ & 900 & $0.36-4.8$ \\
\hline Burdett et al. ${ }^{81}$ & $10 \times 450$ & $850-1066$ & $\begin{array}{l}\mathrm{SO}_{2}(0-5500 \mathrm{ppm}) \\
\mathrm{O}_{2}(0-21 \%) ; \text { bal- } \mathrm{N}_{2}\end{array}$ & $0.5-5$ & Up to 6 & 960 & 0.36 \\
\hline Belo et al. ${ }^{89}$ & $12 \times 250$ & $400-1000$ & $\begin{array}{l}\text { Gas mixture }\left(\mathrm{SO}_{2}-1000\right. \\
\text { ppm, } \mathrm{H}_{2} \mathrm{O}-3 \%, \mathrm{O}_{2}-5 \% \text {, } \\
\left.\text { bal- } \mathrm{N}_{2}\right)\end{array}$ & $0.5-1.5$ & $0.3-0.9$ & 1000 & $0.14-0.77$ \\
\hline Fleig et al..$^{90}$ & $50 \times 900$ & $527-1400$ & $\begin{array}{l}\mathrm{SO}_{2}-1000 \text { ppm, } \mathrm{O}_{2}-3 \% \\
\mathrm{H}_{2} \mathrm{O}-1.11 \% \text {, bal- } \mathrm{N}_{2} / \mathrm{CO}_{2}\end{array}$ & 1.0 & Up to 5 & 1400 & $0.1-1.7$ \\
\hline Duan et al. ${ }^{88}$ & $\begin{array}{l}15.5 \times 1115 \\
(420)^{1}\end{array}$ & $400-700$ & $\begin{array}{l}\mathrm{O}_{2}-6 \%, \mathrm{SO}_{2}-3000 \text { ppm, } \\
\mathrm{H}_{2} \mathrm{O}, \text { bal- } \mathrm{N}_{2} / \mathrm{CO}_{2}\end{array}$ & 3.7 & 1.5 & 700 & $0.1-1.5$ \\
\hline Wang et al..$^{91}$ & $50 \times 1500$ & $350-1050$ & $\begin{array}{l}\mathrm{O}_{2}-5 \%, \mathrm{SO}_{2}-500,1500 \\
2500 \mathrm{ppm}, \mathrm{H}_{2} \mathrm{O}-0.03 \% \\
\text { bal- } \mathrm{CO}_{2}\end{array}$ & 2.0 & $\mathrm{~N} / \mathrm{S}^{2}$ & 950 & $\begin{array}{l}0.11 \\
0.16 \\
0.21\end{array}$ \\
\hline
\end{tabular}




\subsection{Catalytic Effect of Fly Ash}

Metal oxides such as $\mathrm{Fe}_{2} \mathrm{O}_{3}, \mathrm{Al}_{2} \mathrm{O}_{3}$ or $\mathrm{CuO}$ can act as a catalyst in $\mathrm{SO}_{2}$ oxidation, while alkali and earth metal oxides such as $\mathrm{MgO}$ and $\mathrm{CaO}$ can adsorb $\mathrm{SO}_{3} .{ }^{94}$ The catalytic effect of fly ash on $\mathrm{SO}_{3}$ formation in oxy conditions was investigated by Belo et al. ${ }^{89}$ who found that: (i) the total conversion of $\mathrm{SO}_{2}$ to $\mathrm{SO}_{3}$ was only about $1.8 \%$; (ii) the effect of $\mathrm{Fe}_{2} \mathrm{O}_{3}$ was the most pronounced; and (iii) fly ash samples produced under air- and oxy-fuel conditions showed no significant difference. Also, the $\mathrm{SO}_{3}$ concentration increased to $17.8 \mathrm{ppm}$ at $700^{\circ} \mathrm{C}$ in the presence of ash, while only $1 \mathrm{ppm}$ was observed without ash. ${ }^{89}$ A stronger catalytic effect at 400 and $500^{\circ} \mathrm{C}$ was noted by Duan et al. ${ }^{88}$ compared to the tests of Belo et al. ${ }^{89}$ who noted more pronounced catalytic effect at $700^{\circ} \mathrm{C}$. High $\mathrm{CaO}$ content in ash can significantly reduce $\mathrm{SO}_{2}$ concentrations, as noted by Ahn et al. ${ }^{125}$ in the pilot-scale tests with PRB coal $(22.2 \% \mathrm{CaO}$ in ash). By contrast, enhanced $\mathrm{SO}_{3}$ formation was observed for an Illinois coal, which contains $1.9 \% \mathrm{CaO}$ in the ash, and a high sulfur content, as shown in Tables 7 and 8.

Hence, it may be concluded that pronounced catalytic effects were observed in bench-scale tests rather than in the pilot-scale tests. However, large units could perform differently due to the heat transfer rates, inconsistency in fuel composition and loading requirements. Interestingly, the effect of $\mathrm{Fe}$ was not observed in the presence of combustibles in pilot-scale tests of IFK. ${ }^{127}$ For this reason, detailed experiments with a wide range of coals are still required under oxy-fuel combustion conditions to evaluate both catalytic oxidation and absorption by fly ash. 
Table $7 \mathrm{XRF}$ analysis of ashes used for $\mathrm{SO}_{3}$ tests in oxy-fuel tests

\begin{tabular}{|c|c|c|c|c|c|c|c|c|c|c|c|}
\hline Ash analysis & Solid Fuel & $\mathrm{SiO}_{2}$ & $\mathrm{Al}_{2} \mathrm{O}_{3}$ & $\mathrm{Fe}_{2} \mathrm{O}_{3}$ & $\mathrm{CaO}$ & MgO & $\mathrm{Na}_{2} \mathrm{O}$ & $\mathrm{K}_{2} \mathrm{O}$ & $\mathrm{TiO}_{2}$ & $\mathbf{P}_{2} \mathrm{O}_{5}$ & $\mathrm{SO}_{3}$ \\
\hline \multirow{3}{*}{ Belo et al. $^{89}$} & $\mathrm{~A}$ & 52.9 & 34 & 7.13 & 1.41 & 0.98 & 0.158 & 0.518 & 2.16 & 0.275 & 0.24 \\
\hline & $\mathrm{B}$ & 69 & 24.2 & 2.16 & 0.87 & 0.737 & 0.275 & 0.604 & 1.65 & 0.176 & 0.28 \\
\hline & $\mathrm{C}$ & 53 & 26.5 & 8.34 & 4.66 & 1.667 & 0.979 & 1.058 & 1.13 & 1.508 & 0.97 \\
\hline \multirow[t]{3}{*}{ Sporl et al. ${ }^{127}$} & $\mathrm{~A}$ & 58.9 & 26.2 & 6.8 & 1.2 & 0.7 & 0.1 & 0.4 & 2.4 & 0.2 & 0.3 \\
\hline & $\mathrm{B}$ & 64.4 & 21.5 & 1.2 & 0.4 & 0.7 & 02 & 0.4 & 3.9 & 0.0 & 7.2 \\
\hline & $\mathrm{C}$ & 33.2 & 23.0 & 11.4 & 7.0 & 1.8 & 1.3 & 0.9 & 1.2 & 1.8 & 22.7 \\
\hline Couling et al. ${ }^{142}$ & Williamson coal & 50 & 20.5 & 15.9 & 5.18 & 1.14 & 0.68 & 2.41 & 1.05 & 0.1 & 4.78 \\
\hline \multirow[t]{3}{*}{ Ahn et al. ${ }^{125}$} & PRB coal & 30.46 & 14.78 & 5.20 & 22.19 & 5.17 & 1.94 & 0.35 & 1.30 & 1.07 & 8.83 \\
\hline & Utah coal & 60.89 & 14.52 & 5.09 & 6.11 & 1.39 & 1.41 & 0.57 & 0.88 & 0.59 & 2.33 \\
\hline & Illinois coal & 49.28 & 17.66 & 14.57 & 1.87 & 0.98 & 1.51 & 2.26 & 0.85 & 0.11 & 2.22 \\
\hline \multirow[t]{4}{*}{ Kenney et al. ${ }^{143}$} & Sub-Bit coal & 34.56 & 16.05 & 6.16 & 19.79 & 4.23 & 1.24 & 0.50 & 1.29 & 0.81 & 11.67 \\
\hline & Low-S Bit coal & 56.30 & 30.78 & 5.58 & 0.84 & 0.82 & 0.23 & 2.67 & 1.78 & 0.15 & 0.71 \\
\hline & High-S Bit coal & 50.85 & 20.53 & 15.56 & 3.52 & 0.96 & 1.02 & 2.11 & 0.94 & 0.52 & 2.81 \\
\hline & Lignite & 41.99 & 13.96 & 6.47 & 14.84 & 4.50 & 1.56 & 1.93 & 0.54 & 0.18 & 11.99 \\
\hline \multirow[t]{2}{*}{ Duan et al. $^{88}$} & Bituminous coal & 45.12 & 34.14 & 4.16 & 8.66 & 1.36 & 0.462 & 0.99 & 1.53 & 0.09 & 3.06 \\
\hline & Bituminous coal & 37.84 & 18.52 & 10.37 & 19.99 & 4.51 & 2.55 & 0.37 & 1.09 & 1.09 & 3.07 \\
\hline \multirow[t]{2}{*}{ Wang et al. ${ }^{91}$} & Lignite & 64.39 & 18.04 & 3.42 & 4.68 & 1.27 & 0.90 & 0.93 & 0.48 & 0.95 & 4.69 \\
\hline & Bituminous coal & 48.82 & 29.81 & 3.99 & 4.57 & 1.12 & 1.12 & 1.17 & 0.64 & 0.26 & 8.23 \\
\hline \multirow[t]{2}{*}{ Jurado et al. ${ }^{144}$} & Cerrejon coal & 60.69 & 22.01 & 7.43 & 2.27 & 2.90 & 1.06 & 2.32 & 0.92 & 0.21 & \\
\hline & CCP-biomass & 44.36 & 2.49 & 2.47 & 7.78 & 3.96 & 0.36 & 24.72 & 0.12 & 12.04 & \\
\hline
\end{tabular}




\section{4 $\mathrm{SO}_{3}$ Emissions from Pilot-scale Studies}

Ahn et al. ${ }^{125}$ extensively studied $\mathrm{SO}_{3}$ formation in $1.5 \mathrm{MW}$ oxy-PC and $330 \mathrm{~kW}$ oxy-CFB combustor units. Three types of US coals were tested (PRB, Utah and Illinois), and the sulfur content is provided in Table 8. During the oxy-fuel test with Illinois coal $(3.98 \% \mathrm{~S})$ the $\mathrm{SO}_{3}$ concentrations were 4 to 6 times higher at $530^{\circ} \mathrm{C}$. However, similar $\mathrm{SO}_{3}$ concentrations were observed for oxy- and air-combustion at higher temperatures $\left(\sim 930^{\circ} \mathrm{C}\right)$ in $\mathrm{PC}$ tests, and they were lower than those measured at $527^{\circ} \mathrm{C}$, which suggests the secondary formation of $\mathrm{SO}_{3}$ and the catalytic effect of metal oxides in pilot-scale tests. In oxy-CFB only Utah coal was tested, and the trend of $\mathrm{SO}_{3}$ emissions was consistent with that of oxy-PC combustion. However, on a normalised base (mass per energy unit), no difference was found between oxy- and air-firing. $\mathrm{SO}_{3}$ measurements were also undertaken at IFK in a $500 \mathrm{~kW}$ oxy-PC combustor. ${ }^{145}$ In these tests, ESP was included along with $\mathrm{SCR}^{145}$ and the $\mathrm{SO}_{3}$ sampling was made from the inlets and outlets of ESP and SCR. Roughly $62 \% \mathrm{SO}_{3}$ capture was noted in the SCR unit. Higher $\mathrm{SO}_{3}$ levels were noted in oxy-fuel runs and there was less influence of the SCR on the ADP. ${ }^{146,147}$ Babcock-Hitachi tested $\mathrm{SO}_{3}$ emissions in a 1.5 MWth oxy-fuel combustion facility which included SCR, clean energy recuperator (CER), FGR dry precipitator (DESP) and wet electrostatic precipitator (WESP). ${ }^{148}$ Two different coals, with low sulfur, but high ash content, were used in this experimental campaign. $\mathrm{SO}_{3}$ concentration at the DESP outlet was reduced to $<1 \mathrm{ppm}$ by decreasing the flue gas temperature to $90^{\circ} \mathrm{C}$ at the DESP inlet. Similar results were obtained for air- and oxy-fuel combustion. Most $\mathrm{SO}_{3}$ was trapped in the CER unit. ${ }^{148}$ Little data exist in the literature on $\mathrm{SO}_{3}$ formation from oxy-biomass or co-firing combustion. Some $\mathrm{SO}_{3}$ measurements were performed by Jurado et al. ${ }^{144}$ in a $100 \mathrm{~kW}$ oxy-PC unit during co-firing combustion tests. Cerrejon coal/cereal co-products were blended at levels of $50 \% / 50 \%$ and $75 \% / 25 \%$. Wet FGR was employed in these tests with varied steam content. Overall $\mathrm{SO}_{3}$ concentrations appear to show slight increases with an increase of biomass percentage in the mixture, which might be due to the higher content of alkali oxides (primarily $\mathrm{K}_{2} \mathrm{O}$ ) in biomass fly ash. Other $\mathrm{SO}_{3}$ measurements at pilot- and industrial-scale combustors are summarized Table 8 . With regard to $\mathrm{SO}_{3}$ measurement techniques, the CCM method is most commonly used for pilot-scale tests. 
Table 8 A detailed lists of $\mathrm{SO}_{3}$ measurement campaigns under air- and oxy-fuel combustion

\begin{tabular}{|c|c|c|c|c|c|}
\hline Authors & $\begin{array}{l}\text { Type of fuel and } \\
\text { sulfur content }\end{array}$ & Type of reactor & Measurement equipment & $\mathrm{SO}_{3}$ measurement method & $\mathrm{SO}_{3}(\mathrm{ppm})$ \\
\hline $\begin{array}{l}\text { Abele et } \\
\text { al. }{ }^{6}\end{array}$ & $\begin{array}{l}\text { Sub-bituminous (S- } \\
0.57 \% \text { ); }\end{array}$ & & & $\begin{array}{l}\text { Controlled condensation } \\
\text { method }\end{array}$ & Air-0.03; Oxy-0.76; \\
\hline $\begin{array}{l}\text { Tan et } \\
\text { al. }\end{array}$ & $\begin{array}{l}\text { East-bituminous (S- } \\
0.95 \% \text { ); } \\
\text { Sub-bituminous (S- } \\
0.22 \% \text { ); } \\
\text { Lignite (S-0.6\%); }\end{array}$ & $\begin{array}{l}0.3 \mathrm{MW}_{\text {th }} \\
\text { Vertical } \\
\text { combustor }\end{array}$ & $\begin{array}{l}\text { Data acquisition: Honeywell } \\
\text { Series S9000e controller; } \\
\text { Gas analyzer }\end{array}$ & Not specified & $\begin{array}{l}\text { Air-27 ng/J; } \\
\text { Oxy-75 ng/J; } \\
\text { Oxy-0.14 ng/J; }\end{array}$ \\
\hline $\begin{array}{l}\text { Ahn et } \\
\text { al. }{ }^{125}\end{array}$ & $\begin{array}{l}\text { PRB (S wt.\%-0.23), } \\
\text { Utah (S wt.\%-0.53), } \\
\text { Illinois (Swt.\%-3.98) }\end{array}$ & $\begin{array}{l}1.5 \mathrm{MW} \mathrm{PC} \\
\text { combustor; } \\
0.3 \mathrm{MW}_{\text {th }} \mathrm{CFB}\end{array}$ & $\begin{array}{l}\mathrm{SO}_{2} \text { Gas analyzer (CAI } \\
\text { Model } 601 \text { NDIR) and } \\
\text { FTIR (Nicolet Magna-IR } \\
\text { 550) spectrometer }\end{array}$ & $\begin{array}{l}\text { Controlled condensation } \\
\text { method }\end{array}$ & $\begin{array}{l}\text { PRB Air: below } 5^{13} \\
\text { Utah Air: } 5^{13} \\
\text { Utah Oxy: } 5^{13} \\
\text { Illinois Air: } 31^{13} \\
\text { Illinois Oxy: } 117^{13}\end{array}$ \\
\hline $\begin{array}{l}\text { Eddings } \\
\text { et al. }{ }^{149}\end{array}$ & $\begin{array}{l}\text { Illinois coal pellets ( } \mathrm{S} \text { - } \\
4.0 \%)\end{array}$ & $\mathrm{BFB}$ reactor & FTIR & $\begin{array}{l}\text { Controlled condensation } \\
\text { method }\end{array}$ & $\begin{array}{l}\text { Air: } 12^{13} \\
\text { Oxy: } 10^{13}\end{array}$ \\
\hline $\begin{array}{l}\text { Kiga et } \\
\text { al. }{ }^{66,29}\end{array}$ & $\begin{array}{l}\text { Australian low sulfur } \\
\text { coals with: } \\
\text { A (S-0.45\%); } \\
\text { B (S-0.96\%); } \\
\text { C (S-0.38\%); }\end{array}$ & $\begin{array}{l}\text { 1.2 MW IHI Aioi } \\
\text { facility }\end{array}$ & $\begin{array}{l}\text { Non-dispersive infra-red gas } \\
\text { analyzer (HORIBA ENDA- } \\
\text { 1610), Gas chromatography } \\
\text { (Shimadzu 14APFP); }\end{array}$ & & $\begin{array}{l}\text { Coal A: Air-2; } \\
\text { Coal A: Oxy-7; } \\
\text { Coal B: Air-9; } \\
\text { Coal B: Oxy-9; } \\
\text { Coal C: Air-3; } \\
\text { Coal C: Oxy-11; }\end{array}$ \\
\hline $\begin{array}{l}\text { Fleig et } \\
\text { al. }{ }^{103}\end{array}$ & $\begin{array}{l}\text { Propane and } \mathrm{SO}_{3} \\
\text { injected to unit; }\end{array}$ & $\begin{array}{l}100 \mathrm{~kW} \text { Oxy- } \\
\text { fired test unit } \\
\text { combustor }\end{array}$ & $\begin{array}{l}\text { Nondispersive infrared } \\
\text { (NDIR) analyzers (NGA } \\
2000 \text { Fisher Rosemount); IC } \\
\text { (ICS -90 DIONEX) }\end{array}$ & $\begin{array}{l}\text { Controlled condensation } \\
\text { method used as reference case } \\
\text { to other methods: } \\
\text { 1. Isopropanol absorption } \\
\text { bottle method; } \\
\text { 2. Salt method; } \\
\text { 3. Pentol } \mathrm{SO}_{3} \text { monitor }\end{array}$ & $\begin{array}{l}\text { CCM results: } \\
\text { Air case: } 34 ; \text { Oxy-case } 25^{14}: 9 \text {; } \\
\text { Oxy-case } 30^{14}: 56 ; \text { Oxy-case } \\
35: 25\end{array}$ \\
\hline
\end{tabular}




\begin{tabular}{|c|c|c|c|c|c|}
\hline Authors & $\begin{array}{l}\text { Type of fuel and } \\
\text { sulfur content }\end{array}$ & Type of reactor & Measurement equipment & $\mathrm{SO}_{3}$ measurement method & $\mathrm{SO}_{3}(\mathrm{ppm})$ \\
\hline $\begin{array}{l}\text { Vainio et } \\
\text { al. }{ }^{111}\end{array}$ & $\begin{array}{l}\text { Mixture of gases: }\left(\mathrm{SO}_{2},\right. \\
\left.\mathrm{H}_{2} \mathrm{O}, \mathrm{O}_{2}, \mathrm{~N}_{2} \text { and } \mathrm{H}_{2} \mathrm{SO}_{4}\right)\end{array}$ & $\begin{array}{l}\text { Bench-scale } \\
\text { horizontal tube } \\
\text { reactor }\end{array}$ & $\begin{array}{l}\text { ICS-90 Ion chromatography } \\
\text { (DIONEX) }\end{array}$ & $\begin{array}{l}\text { Salt method: four types of salts } \\
\text { tested }\left(\mathrm{NaCl}, \mathrm{KCl}, \mathrm{K}_{2} \mathrm{CO}_{3} \text {, }\right. \\
\left.\mathrm{CaCl}_{2}\right)\end{array}$ & $\begin{array}{l}\text { Salt method results: } \mathrm{NaCl} \text { : Air } \\
-30^{1} \text {; } \\
\mathrm{NaCl} \text { : Oxy }-46^{1} \text {; }\end{array}$ \\
\hline $\begin{array}{l}\text { Spörl et } \\
\text { al. }{ }^{150}\end{array}$ & $\begin{array}{l}\text { Australian coals with } \\
\text { sulfur: (A-0.3\%; B- } \\
0.7 \% \text {; C-0.7\%) }\end{array}$ & $\begin{array}{l}20 \mathrm{~kW} \\
\text { combustion rig; } \\
\mathrm{L} \times \mathrm{D}(2.5 \times 0.2 \\
\mathrm{m}) ; \\
\text { Flow rate: } 11.5 \\
\mathrm{~m}^{3} / \mathrm{h}\end{array}$ & IC (DIN EN ISO 10304) & $\begin{array}{l}\text { Controlled condensation } \\
\text { method }\end{array}$ & $\begin{array}{l}\text { Coal A: Air }-2 \text {; } \\
\text { Oxy: } 6-35^{3} ; \\
\text { Coal B: Air }-8 \text {; } \\
\text { Oxy: } 18-50 ; \\
\text { Coal C: Air }-1 \text {; } \\
\text { Oxy: } 2-30\end{array}$ \\
\hline $\begin{array}{l}\text { Monckert } \\
\text { et al. }{ }^{147}\end{array}$ & $\begin{array}{l}\text { Klein Kopje, Lausitz, } \\
\text { Rhenish, Ensdorf coals } \\
\text { (S-1\%) }\end{array}$ & $\begin{array}{l}0.5 \mathrm{MW} \text { down- } \\
\text { fired Oxy-PC }\end{array}$ & SEM-BSE, SEM-MAP & $\begin{array}{l}\text { Controlled condensation } \\
\text { method }\end{array}$ & $\begin{array}{l}\text { Air: } 8 \\
\text { Oxy: } 85\end{array}$ \\
\hline $\begin{array}{l}\text { Roy et } \\
\text { al. }{ }^{117}\end{array}$ & $\begin{array}{l}\text { Victorian coals Loy } \\
\text { Yang, Morvell and } \\
\text { Yallourn (S- } 0.5 \%)\end{array}$ & $\begin{array}{l}10 \mathrm{~kW} \text { oxy-fired } \\
\text { BFB }\end{array}$ & $\begin{array}{l}\text { Gas analyzer (MX6 iBrid) } \\
\text { GC (Agilent GC 7890A); }\end{array}$ & $\begin{array}{l}\text { Calcium oxalate with glass } \\
\text { beads }\end{array}$ & $\begin{array}{l}\text { Dry Oxy: } 11 \text { mg/MJ; Air: } 15 \\
\text { mg/MJ; Dry Oxy-fuel } 14 \\
\text { mg/MJ; }\end{array}$ \\
\hline $\begin{array}{l}\text { Duan et } \\
\text { al. }^{88}\end{array}$ & $\begin{array}{l}\text { Fly ash, bituminous } \\
\text { coal (S- } 0.5 \%)\end{array}$ & $50 \mathrm{~kW}$ oxy-CFB & $\begin{array}{l}\text { Titration; IC DX-120 } \\
\text { (DIONEX) }\end{array}$ & $\begin{array}{l}\text { Controlled condensation } \\
\text { method }\end{array}$ & Air-2, Oxy-8; \\
\hline $\begin{array}{l}\text { Wang et } \\
\text { al. }{ }^{91}\end{array}$ & $\begin{array}{l}\text { Lignite coal (S-0.6\%); } \\
\text { Bituminous coal (S- } \\
3.69 \% \text { ) }\end{array}$ & Oxy PC unit & ICS -90 DIONEX & $\begin{array}{l}\text { Controlled condensation } \\
\text { method }\end{array}$ & $\begin{array}{l}\text { Oxy Bituminous coal: } \\
\left.\text { (500 to } 3000 \text { ppm } \mathrm{SO}_{2}\right) ; 13 \text { to } \\
\text { 105; Oxy Lignite: } \\
\left(500 \text { to } 3000 \text { ppm } \mathrm{SO}_{2}\right) ; 0.5 \text { to } \\
80 ;\end{array}$ \\
\hline Hemis $^{31}$ & Illinois bituminous coal & $\begin{array}{l}\text { Hoosier Energy' } \\
\text { Merom Station }\end{array}$ & $\begin{array}{l}\text { FTIR; IC (Desert } \\
\text { Analytics); }\end{array}$ & $\begin{array}{l}\text { FTIR and Controlled } \\
\text { condensation method }\end{array}$ & $\begin{array}{l}\text { Air tests: Day-1 FTIR-37.33 } \\
\text { versus CCM-30.4; Day-2 } \\
\text { FTIR-37.66 vs CCM-29.1; }\end{array}$ \\
\hline $\begin{array}{l}\text { Cao et } \\
\text { al. }{ }^{100}\end{array}$ & $\begin{array}{l}\text { Bituminous and } \\
\text { subbituminous coals (S- } \\
3.5 \%) \text {; }\end{array}$ & $\begin{array}{l}\text { Fixed bed } \\
\text { reactor, }\end{array}$ & IC (DX-120); & $\begin{array}{l}\text { Modified controlled } \\
\text { condensation method }\end{array}$ & $\begin{array}{l}\text { Air. Site1: Bituminous coal } \\
\text { SCR inl-22; SCR out-24; Air } \\
\text { preheater out-7; ESP in-6; }\end{array}$ \\
\hline
\end{tabular}




\begin{tabular}{|c|c|c|c|c|c|}
\hline Authors & $\begin{array}{l}\text { Type of fuel and } \\
\text { sulfur content }\end{array}$ & Type of reactor & Measurement equipment & $\mathrm{SO}_{3}$ measurement method & $\mathrm{SO}_{3}(\mathrm{ppm})$ \\
\hline & Three types of fly ashes & $\begin{array}{l}\text { Full-scale utility } \\
\text { boilers }\end{array}$ & & & $\begin{array}{l}\text { FGD inl-7; FGD out-4; Site 2: } \\
\text { SCR inl-23; SCR out-24; Air } \\
\text { preheater out-21; ESP out-17; } \\
\text { FGD inl-17.5; FGD out-15; } \\
\text { Site 3: Sub-bituminous: below } \\
2 \text { at all locations }\end{array}$ \\
\hline $\begin{array}{l}\text { Kenney et } \\
\text { al. }^{143}\end{array}$ & $\begin{array}{l}\mathrm{LSB}^{4}(\mathrm{~S}-0.9 \%) \\
\mathrm{HSB}^{5}(\mathrm{~S}-3.2 \%) \\
\text { Sub-bituminous }(\mathrm{S}-0.3 \\
\%) \\
\text { Dried lignite }(\mathrm{S}-0.7 \%)\end{array}$ & $\begin{array}{l}\text { Oxy-fired pilot } \\
\text { plant } \\
15 \mathrm{MW}_{\mathrm{th}} \\
\text { Alstom; }\end{array}$ & N/A & $\begin{array}{l}\mathrm{SO}_{3} \text { executed from four } \\
\text { locations of boiler; } \\
\text { Controlled condensation } \\
\text { method. }\end{array}$ & $\begin{array}{l}\text { Sub-bit Air: } 0.5^{1} ; \text { Oxy with } \\
\text { SO }_{x} \text { control: } 1.6^{1} ; \text { LSB air: } \\
\text { 28.8; oxy: } 39.4 ; \text { HSB air-41; } \\
\text { Oxy-186.3; Lignite air-30; } \\
\text { oxy-45.9; }\end{array}$ \\
\hline $\begin{array}{l}\text { Jurado et } \\
\text { al. }{ }^{144}\end{array}$ & $\begin{array}{l}\text { EI Cerrejon coal (S- } \\
0.58 \%) ; \text { Cereal co- } \\
\text { product }(\mathrm{S}-0.16 \%)\end{array}$ & $\begin{array}{l}0.1 \mathrm{MW} \\
\text { pulverized oxy- } \\
\text { fuel combustor }\end{array}$ & FTIR, ESEM/EDX, XRD & $\begin{array}{l}\text { Controlled condensation } \\
\text { method }\end{array}$ & $\begin{array}{l}\text { Air: EC-3.7; EC/CC (50/50\%)- } \\
\text { 20.2; CC-25.4; Oxy: EC-20.6; } \\
\text { EC/CC (50/50\%)-35.9; EC/CC } \\
(75 / 25 \%)-16.8 ;\end{array}$ \\
\hline Davis $^{151}$ & $\begin{array}{l}\text { USA Williamson coal } \\
(\mathrm{S}-1.7 \%)\end{array}$ & $\begin{array}{l}\text { E.ON } 1 \mathrm{MW} \\
\text { Combustion Test } \\
\text { Facility }\end{array}$ & $\mathrm{XRF}, \mathrm{SEM}$ & $\begin{array}{l}\mathrm{SO}_{3} \text { Monitor (Severn Science } \\
\text { analyzer); } \\
\text { Controlled condensation } \\
\text { method }\end{array}$ & Not specified; \\
\hline $\begin{array}{l}\text { Dhungel } \\
\text { et al. }{ }^{67}\end{array}$ & $\begin{array}{l}\text { Medium Sulfur } \\
\text { Bituminous Coal }\end{array}$ & $\begin{array}{l}\text { Emission } \\
\text { reduction test } \\
\text { facility } 0.16 \mathrm{MW} \\
\text { oxy-fired system; }\end{array}$ & $\begin{array}{l}\text { Dry sorbent injection; } \\
\text { Gas analyzer }\end{array}$ & $\begin{array}{l}\text { Controlled condensation } \\
\text { method }\end{array}$ & $\begin{array}{l}\text { Not specified; roughly } 3 \text { to } 5 \\
\text { times higher in oxy-fuel }\end{array}$ \\
\hline $\begin{array}{l}\text { Stanger et } \\
\text { al. }^{152}\end{array}$ & Callide coal S-0.3 & $\begin{array}{l}\text { Callide oxy-fuel } \\
\text { plant }\end{array}$ & & $\begin{array}{l}\text { Controlled condensation } \\
\text { method }\end{array}$ & $\begin{array}{l}\text { Air }<0.06 \\
\text { Oxy: 0.6-3.7 }\end{array}$ \\
\hline
\end{tabular}

${ }^{1}$ Average value is presented; 2 . Oxy-25/30: $25 \%$ or $30 \%$ of $\mathrm{O}_{2}$ in the oxidizer stream; ${ }^{3}$ Range of $\mathrm{SO}_{3}$ values is provided for this particular test as initial parameters were different; 4 LSB-low sulfur bituminious; ${ }^{5}$ HSB- high sulfur bituminious; 


\subsection{Modelling Studies of $\mathrm{SO}_{3}$ Formation}

Only a few numerical studies on $\mathrm{SO}_{3}$ formation are available in the open literature for oxy- as compared to air-combustion. Burdett et al. ${ }^{81}$ simulated the effect of operating bed pressure on $\mathrm{SO}_{2}$-to- $\mathrm{SO}_{3}$ conversion for air-combustion. The predictions for bed pressure $(600 \mathrm{kPa})$ and temperature of $900^{\circ} \mathrm{C}$ with $10 \%$ of $\mathrm{O}_{2}$ in the flue gas clearly indicated increasing $\mathrm{SO}_{3}$ formation with increasing oxygen formation. This work suggests that under such conditions the potential conversion of sulfur-in-fuel to $\mathrm{SO}_{3}$ could be as high as $20 \%$. Fleig et al. ${ }^{126}$ modelled homogeneous gas-phase $\mathrm{SO}_{3}$ formation for oxy-fuel combustion conditions with a model which is described by Giménez-Lopez et al. ${ }^{79}$ and which was initially developed by Glarborg et al. ${ }^{153}$ CHEMKIN-PRO was used to model homogeneous reactions considering plug flow reactor. More recently, Belo et al. ${ }^{89}$ implemented a kinetic model of Burdett et al. ${ }^{81}$ for residence time of 0.3 to $0.9 \mathrm{~s}$ (Table 6). Due to thermodynamic considerations, the maximum conversion of $\mathrm{SO}_{2}$ to $\mathrm{SO}_{3}$ was at low temperatures and further increases of temperature to 900 and $1000^{\circ} \mathrm{C}$ decreased the $\mathrm{SO}_{3}$ by $\sim 6.8$ and $\sim 3.2 \%$, respectively. ${ }^{89} \mathrm{SO}_{3}$ formation was also modelled by Schneider and Bogdan, ${ }^{154}$ for an oil-fired boiler.

\section{Research Needs}

A significant amount of effort has been made to evaluate $\mathrm{SO}_{3}$ concentrations from laboratory-scale to commercial-scale units. However, oxy-fuel combustion requires more attention in terms of better understanding $\mathrm{SO}_{3}$ formation mechanisms. At this point the majority of $\mathrm{SO}_{3}$ measurements have been conducted in conventional PC and gas-fired combustion systems, while only a few studies are available for oxy-fired FB combustors and pilot-scale studies are still sparse. Major research should concentrate on the effect of FGR and catalytic conversion. $\mathrm{SO}_{3}$ formation both depend on gases such as $\mathrm{NO}, \mathrm{CO}$ and their effects may be different in oxy-fuel combustion and, hence more experiments are needed on $\mathrm{SO}_{3}$ formation with different types of coals. Development of pressurized FBC systems would also require $\mathrm{SO}_{3}$ formation tests as experimental data on the effect of pressure are rare.

In the case of analytical methods, all the current post-combustion $\mathrm{SO}_{3}$ measurements still have technical challenges associated mainly with temperature control as $\mathrm{SO}_{3}$ is a very 
reactive molecule and $\mathrm{SO}_{3}$ can easily be lost in the sampling line. At present, $\mathrm{CCM}$ is the most used and reliable technique to quantify $\mathrm{SO}_{3}$ concentrations, while other methods such as the salt method or calcium oxalate with glass beads need to be improved.

\section{Conclusions}

The present paper reviews the formation $\mathrm{SO}_{3}$ in coal combustion systems, and especially oxy-fuel technology. The following conclusions can be drawn:

- $\mathrm{SO}_{3}$ concentration in oxy-fuel combustion is typically several times higher than that in air combustion. The higher level of $\mathrm{SO}_{3}$ is mainly due to the increased concentrations of $\mathrm{O}_{2}, \mathrm{H}_{2} \mathrm{O}$ and $\mathrm{SO}_{2}$ in the boiler

- Wet flue gas recycling is associated with higher $\mathrm{SO}_{3}$ concentration than dry flue gas recycling. An increased amount of $\mathrm{H}_{2} \mathrm{O}$ promotes $\mathrm{SO}_{3}$ formation apparently due to the production of $\mathrm{OH}$ radicals. However, $\mathrm{H}_{2} \mathrm{O}$ concentrations higher than $15 \%$ in the system strongly inhibit $\mathrm{SO}_{3}$ formation. Inhibition appears to be more pronounced in actual PC tests than in simulated flue gas tests.

- Higher conversion of $\mathrm{S}$ to $\mathrm{SO}_{3}$ occurs near the burnout region where $\mathrm{O}_{2}$ is found in excess amounts. In this region, gas-phase homogeneous formation is dominant for $\mathrm{SO}_{3}$ formation.

- The presence of gases such as $\mathrm{NO}$ and $\mathrm{CO}$ may enhance $\mathrm{SO}_{3}$ formation. However, these effects appear to be small compared to other factors such as combustion temperature, excess $\mathrm{O}_{2}$ and presence of catalysts.

- $\mathrm{SO}_{3}$ formation is enhanced due to catalytic effect of fly ash. Higher concentrations of $\mathrm{Fe}_{2} \mathrm{O}_{3}$ and $\mathrm{V}_{2} \mathrm{O}_{5}$ and other metal oxides increase $\mathrm{SO}_{3}$ concentrations significantly. Adsorption of $\mathrm{SO}_{3}$ by alkali and alkaline earth metal oxides is also an important phenomenon.

- The CCM method appears to be the most dependable technique for measuring $\mathrm{SO}_{3}$ concentrations.

\section{Acknowledgements}

The authors would like to thank Dr Nelia Jurado from Cranfield University (UK) and Dr Emil Vainio from Abo Akademi (Finland) for useful advice on the controlled- 
condensation method (CCM) and the salt method, and also for providing valuable information. The financial support from Nazarbayev University under "Talap" studentship is also greatly acknowledged. This work was completed as part of a $\mathrm{PhD}$ program at Cranfield University for one of us (YS). 


\section{References}

1. IEA, Tracking Clean Energy Progress 2016, Energy Technology Perspectives 2016 Excerpt IEA Input to the Clean Energy Ministerial, (2016).

2. IEA, $\mathrm{CO}_{2}$ Emissions from fuel combustion, Highlights, (2017).

3. IPCC, IPCC special report on carbon dioxide capture and storage. Prepared by Working Group III of the Intergovernmental Panel on Climate Change, ed by Metz B, Davidson O, de Coninck HC, Loos M and Meyer LA. Cambridge University Press, Cambridge, United Kingdom and New York, NY, USA (2005).

4. Toftegaard MB, Brix J, Jensen PA, Glarborg P and Jensen AD, Oxy-fuel combustion of solid fuels. Prog Energy Combust Sci 36(5):581-625 (2010).

5. Buhre BJP, Elliott LK, Sheng CD, Gupta RP and Wall TF, Oxy-fuel combustion technology for coal-fired power generation. Prog Energy Combust Sci 31(4):283307 (2005).

6. Abele AR, Kindt GS, Clark WD, Payne R and Chen SL. An experimental program to test the feasibility of obtaining normal performance from combustors using oxygen and recycled gas instead of air, Report ANL/CNSV-TM-204, Argonne National Laboratory, Argonne, (1987).

7. Edge P, Gharebaghi M, Irons R, Porter R, Porter RTJ, Pourkashanian M et al., Combustion modelling opportunities and challenges for oxy-coal carbon capture technology. Chem Eng Res Des 89:1470-1493 (2011).

8. Wall T, Liu Y, Spero C, Elliot L, Khare S, Rathnam R et al., An overview on oxyfuel coal combustion-State of the art research and technology development. Chem Eng Res Des 87(8):1003-1016 (2009).

9. Liu H, Shao Y. Predictions of the impurities in the $\mathrm{CO}_{2}$ stream of an oxy-coal combustion plant. Appl Energy 87(10):3162-3170 (2010).

10. IEA, Energy Technology Perspectives 2012; Pathways to a Clean Energy System. IEA, Paris, France (2012).

11. Davison J. Performance and costs of power plants with capture and storage of $\mathrm{CO}_{2}$. Energy 32(7):1163-1176 (2007).

12. Müller M, Schnell U, Grathwohl S, Maier J and Scheffknecht G, Evaluation of oxy-coal combustion modelling at semi-industrial scale. Energy Procedia 23:197206 (2012).

13. Wall TF. Combustion processes for carbon capture. Proc Combust Inst 31 (1):3147 (2007).

14. Jordal K, Anheden M, Yan J and Strömberg L, Oxyfuel combustion for coal-fired power generation with $\mathrm{CO}_{2}$ capture - Opportunities and challenges. In: The 7th International Conference on Greenhouse Gas Control Technologies (GHGT-7), September. Vancouver, Canada, (2004).

15. Anheden M, Rydberg S and Yan J, Consideration for removal of non- $\mathrm{CO}_{2}$ components from $\mathrm{CO}_{2}$ rich flue gas of oxy- fuel combustion. In: IEA Oxyfuel Workshop. (2008). 
16. Dillon DJ, White V, Allam RJ, Wall RA and Gibbins J, Oxy-combustion processes for $\mathrm{CO}_{2}$ capture from power plant. Mitsui Babcock Energy Limited, Engineering investigation report No. 2005/9, IEA greenhouse gas R\&D programme (2005).

17. Gibbins J, Chalmers H. Carbon capture and storage. Energy Policy 36(12):43174322 (2008).

18. Markewitz P, Kuckshinrichs W, Leitner W, Linssen J, Zapp P, Bongartz R et al., Worldwide innovations in the development of carbon capture technologies and the utilization of $\mathrm{CO}_{2}$. Energy Environ. Sci 5:7281-7305 (2012).

19. de Visser E, Hendriks C, Barrio M, Mölnvik MJ, de Koeijer G, Liljemark S et al., Dynamis $\mathrm{CO}_{2}$ quality recommendations. Int J Greenh Gas Control 2(4):474-484 (2008).

20. Andersson K, Johnsson F. Process evaluation of an $865 \mathrm{MWe}$ lignite fired $\mathrm{O}_{2} / \mathrm{CO}_{2}$ power plant. Energy Convers Manag 47(18-19):3487-3498 (2006).

21. Aspelund A, Jordal K. Gas conditioning-The interface between $\mathrm{CO}_{2}$ capture and transport. Int J Greenh Gas Control 1(3):343-354 (2007).

22. Burnol A, Thinon I, Ruffine L and Herri JM, Influence of impurities (nitrogen and methane) on the $\mathrm{CO}_{2}$ storage capacity as sediment-hosted gas hydrates Application in the area of the Celtic Sea and the Bay of Biscay. Int J Greenh Gas Control 35:96-109 (2015).

23. Li H, Yan J, Yan J and Anheden M, Impurity impacts on the purification process in oxy-fuel combustion based $\mathrm{CO}_{2}$ capture and storage system. Appl Energy 86(2):202-213 (2009).

24. IEAGHG "Effects of Impurities on Geological Storage of $\mathrm{CO}_{2}$ ", 2011/04, June, 2011 Available at:

http://hub.globalccsinstitute.com/sites/default/files/publications/16876/effectsimpurities-geological-storage-co2.pdf [Accessed 01 December 2017].

25. Talman S. Subsurface geochemical fate and effects of impurities contained in a $\mathrm{CO}_{2}$ stream injected into a deep saline aquifer: What is known. Int J Greenh Gas Control 40:267-291 (2015).

26. White V, Torrente-Murciano L, Sturgeon D and Chadwick D, Purification of oxyfuel-derived $\mathrm{CO}_{2}$. Int J Greenh Gas Control 4(2):137-142 (2010).

27. Cheng J, Zhou J, Liu J, Zhou J, Huang Z, Cao X et al., Sulfur removal at high temperature during coal combustion in furnaces: a review. Prog Energy Combust Sci 29(5):381-405 (2003).

28. Anthony EJ, Granatstein DL. Sulfation phenomena in fluidized bed combustion systems. Prog Energy Combust Sci 27(2):215-236 (2001).

29. Stanger R, Wall T. Sulphur impacts during pulverised coal combustion in oxyfuel technology for carbon capture and storage. Prog Energy Combust Sci 37(1):69-88 (2011). 
30. Srivastava RK, Miller CA, Erickson C and Jambhekar R, Emissions of sulfur trioxide from coal-fired power plants. J air waste Manag Assoc 54:750-762 (2004).

31. Continuous Measurement of $\mathrm{SO}_{3}$ in a Coal-Fired Power Plant. EPRI, Palo Alto, CA, 2006. 1010375.

32. Attar A. Chemistry, thermodynamics and kinetics of reactions of sulphur in coalgas reactions: A review. Fuel 57(4):201-212 (1978).

33. Raask E. Sulphate capture in ash and boiler deposits in relation to $\mathrm{SO}_{2}$ emission. Prog Energy Combust Sci 8(4):261-276 (1982).

34. Glarborg P. Hidden interactions-Trace species governing combustion and emissions. Proc Combust Inst 31(1):77-98 (2007).

35. Cullis CF, Mulcahy MFR. The kinetics of combustion of gaseous sulphur compounds. Combust Flame 18(2):225-292 (1972).

36. Glassman I, Yetter RA, Combustion, Fourth Edition. Academic press Elsevier. pp. 421-420 (2008).

37. Zygarlicke CJ, Stomberg AL, Folkedahl BC and Strege JR, Alkali influences on sulfur capture for North Dakota lignite combustion. Fuel Process Technol 87(10):855-861 (2006).

38. Croiset $\mathrm{E}$, Thambimuthu $\mathrm{KV} . \mathrm{NO}_{\mathrm{x}}$ and $\mathrm{SO}_{2}$ emissions from $\mathrm{O}_{2} / \mathrm{CO}_{2}$ recycle coal combustion. Fuel 80(14): 2117-2121 (2001).

39. Fleig D, Andersson K, Johnsson F and Leckner B, Conversion of sulfur during pulverized oxy-coal combustion. Energy Fuels 25(2):647-655 (2011).

40. Cutler AJB, Raask E. External corrosion in coal-fired boilers: assessment from laboratory data. Corros Sci 21(11):789-800 (1981).

41. Sheng $\mathrm{C}, \mathrm{Xu} \mathrm{M}$, Zhang J and Xu Y, Comparison of sulphur retention by coal ash in different types of combustors. Fuel Process Technol 64(1-3):1-11 (2000).

42. Vuthaluru HB, Zhang D and Linjewile TM, Behaviour of inorganic constituents and ash characteristics during fluidised-bed combustion of several Australian lowrank coals. Fuel Process Technol 67(3):165-176 (2000).

43. Bryers RW. Fireside slagging, fouling, and high-temperature corrosion of heattransfer surface due to impurities in steam-raising fuels. Prog Energy Combust Sci 22(1):29-120 (1996).

44. Harb JN, Smith EE. Fireside corrosion in pc-fired boilers. Prog Energy Combust Sci 16(3):169-190 (1990).

45. Shamanna S, Schobert HH. Fireside corrosion of selected alloys by ash recovered from coal-water slurry combustion, Fuel Process Technol 53(1-3):133-156 (1997).

46. James DW, Krishnamoorthy G, Benson SA and Seames WS, Modelling trace element partitioning during coal combustion. Fuel Process Technol 126:284-297 (2014). 
47. Moser RE. Benefits of effective $\mathrm{SO}_{3}$ removal in coal-fired power plants: beyond opacity control. In: Power Plant Air Pollutant Control, Mega Symposium, August 28-31, Baltimare, MD (2006).

48. Nielsen MT. On the relative importance of $\mathrm{SO}_{2}$ oxidation to high dust SCR DeNOx units. In: DOE/NETL 2003 Conference on Selective Catalytic Reduction (SRC) and Selective Non-Catalytic Reduction (SNCR) for NOx Control, pp. 1-12 (2003).

49. Fleig D, Normann F, Andersson K, Johnsson F and Leckner B, The fate of sulphur during oxy-fuel combustion of lignite. Energy Procedia 1(1):383-390 (2009).

50. Fleig D, Andersson $\mathrm{K}$ and Johnsson $\mathrm{F}$, Influence of operating conditions on $\mathrm{SO}_{3}$ formation during air and oxy-fuel combustion. Ind Eng Chem Res 51(28):94839491 (2012).

51. Tan Y, Croiset E, Douglas MA and Thambimuthu KV, Combustion characteristics of coal in a mixture of oxygen and recycled flue gas. Fuel 85(4):507-512 (2006).

52. Reid WT. External Corrosion and Deposits Boilers and Gas Turbines. (Elsevier, ed), New York (1971).

53. Svachula J, Alemany LJ, Ferlazzo N, Forzatti P and Tronconi E, Oxidation of $\mathrm{SO}_{2}$ to $\mathrm{SO}_{3}$ over honeycomb DeNoxing Catalysts. Ind Eng Chem Res 32:826-834 (1993).

54. EPRI, $\mathrm{SO}_{3}$ Mitigation Guide, EPRI Report TR-104424, Research Project 225003,Prepared by Radian Corporation, Austin, Texas. Principal investigators Peterson J, Jones AF. October (1994).

55. Shanthakumar S, Singh DN and Phadke RC, Flue gas conditioning for reducing suspended particulate matter from thermal power stations. Prog Energy Combust Sci. 34(6):685-695 (2008).

56. Sjostrom S, Dillon M, Donnelly B, Bustard J, Filippelli G, Glesmann R et al., Influence of $\mathrm{SO}_{3}$ on mercury removal with activated carbon: Full-scale results. Fuel Process Technol 90(11):1419-1423 (2009).

57. Hu Y, Yan J. Characterization of flue gas in oxy-coal combustion processes for $\mathrm{CO}_{2}$ capture. Appl Energy 90(1):113-121 (2012).

58. Boot-Handford ME, Abanades JC, Anthony EJ, Blunt MJ, Brandani S, Mac Dowell N et al., Carbon capture and storage update. Energy Environ Sci 7(1):130189 (2014).

59. Kather A, Scheffknecht G. The oxycoal process with cryogenic oxygen supply. Naturwissenschaften 96(9):993-1010 (2009).

60. Nakayama S, Noguchi Y, Kiga T, Miyamae S, Maeda U, Kawai M et al., Pulverized coal combustion in $\mathrm{O}_{2} / \mathrm{CO}_{2}$ mixtures on a power plant for $\mathrm{CO}_{2}$ recovery. Energy Convers Manag 33(5-8):379-386 (1992). 
61. Normann F, Andersson K, Leckner B and Johnsson F, Emission control of nitrogen oxides in the oxy-fuel process. Prog Energy Combust Sci 35(5):385-397 (2009).

62. Molburg JC, Doctor RD, Brockmeier NF and Plasynski S, $\mathrm{CO}_{2}$ capture from PC boilers with $\mathrm{O}_{2}$-firing. In: 18th Annual International Pittsburgh Coal Conference, December 4-7, Newcastle, New South Wales, Australia (2001).

63. Review of $\mathrm{CO}_{2}$-Capture Development Activities for Coal-Fired Power Generation Plants, EPRI, Palo Alto, CA: 2007: 1012239.

64. Zanganeh KE, Shafeen A. A novel process integration, optimization and design approach for large-scale implementation of oxy-fired coal power plants with $\mathrm{CO}_{2}$ capture. Int J Greenh Gas Control 1(1):47-54 (2007).

65. Günther C, Weng M and Kather A, Restrictions and limitations for the design of a steam generator for a coal-fired oxyfuel power plant with circulating fluidised bed combustion. Energy Procedia 37:1312-1321 (2013).

66. Kiga T, Takano S, Kimura N, Omata K, Okawa M, Mori T et al., Characteristics of pulverized-coal combustion in the system of oxygen/recycled flue gas combustion. Energy Convers Manag 38:S129-S134 (1997).

67. Dhungel B, Ellul C, Gibson JR and Fitzgerald FD, $\mathrm{SO}_{3}$ Control in Oxyfuel Applications. In: IEAGHG Special Workshop on Oxyfuel Combustion. London: IEA Greenhouse Gas R\&D Programme (2011).

68. Fleig D, Andersson K, Kühnemuth D, Normann F, Johnsson F and Leckner B. The sulphur mass balance in oxy-fuel combustion of lignite - an experimental study. In: 1st Oxyfuel Combustion Conference, Cottbus, 8-11 ${ }^{\text {th }}$ September (2009). Available at: http://www.ieaghg.org/docs/oxyfuel/OCC1/Session\%205_A/Cottbus\%20Daniel\% 20Fleig.pdf [accessed 5 March 2017].

69. Duan L, Sun H, Zhao C, Zhou C. Zhou W and Chen X, Coal combustion characteristics on an oxy-fuel circulating fluidized bed combustor with warm flue gas recycle. Fuel 127:47-51 (2014).

70. Durie RA, Matthews CJ and Smith MY, The catalytic formation of sulfur trioxide in fuel-rich propane-air flames. Combust Flame 15(2):157-165 (1970).

71. Zachariah MR, Smith OI. Experimental and numerical studies of sulfur chemistry in $\mathrm{H}_{2} / \mathrm{O}_{2} / \mathrm{SO}_{2}$ flames. Combust Flame 69(2):125-139 (1987).

72. Miccio F, Löffler G, Wargadalam VJ and Winter F, The influence of $\mathrm{SO}_{2}$ level and operating conditions on $\mathrm{NO}_{\mathrm{x}}$ and $\mathrm{N}_{2} \mathrm{O}$ emissions during fluidised bed combustion of coals. Fuel 80(11):1555-1566 (2001).

73. Schäfer S, Born B. Hydrolysis of HCN as an important step in nitrogen oxide formation in fluidised combustion. Part II: heterogeneous reactions involving limestone. Fuel 81(13):1641-1646 (2002).

74. Wendt JOL, Ekmann JM. Effect of fuel sulfur species on nitrogen oxide emissions from premixed flames. Combust Flame 25:355-360 (1975). 
75. Wendt JOL, Wootan EC and Corley TL, Postflame behavior of nitrogenous species in the presence of fuel sulfur I. Rich, moist $\mathrm{CO} / \mathrm{Ar} / \mathrm{O}_{2}$ flames. Combust Flame 49(1-3):261-274 (1983).

76. Corley TL, Wendt JOL. Postflame behavior of nitrogenous species in the presence of fuel sulfur II. Rich, $\mathrm{CH}_{4} / \mathrm{He} / \mathrm{O}_{2}$ flames. Combust Flame 58(2):141-152 (1984).

77. Glarborg P, Kubel D, Dam-Johansen K, Chiang HM and Bozzelli JW, Impact of $\mathrm{SO}_{2}$ and $\mathrm{NO}$ on $\mathrm{CO}$ oxidation under post-flame conditions. Int J Chem Kin 28(10):773-790 (1996).

78. Rasmussen CL, Glarborg $\mathrm{P}$ and Marshall $\mathrm{P}$, Mechanisms of radical removal by $\mathrm{SO}_{2}$. Proc Combust Inst 31(1):339-347 (2007).

79. Giménez-López J, Martínez M, Millera A, Bilbao R and Alzueta MU, $\mathrm{SO}_{2}$ effects on $\mathrm{CO}$ oxidation in a $\mathrm{CO}_{2}$ atmosphere, characteristic of oxy-fuel conditions. Combust Flame 158(1):48-56 (2011).

80. Jørgensen TL. Livbjerg H and Glarborg P, Homogeneous and heterogeneously catalyzed oxidation of $\mathrm{SO}_{2}$. Chem Eng Sci 62(16):4496-4499 (2007).

81. Burdett NA, Langdon WE and Squires RT, Rate of the coefficients for the reaction $\mathrm{SO}_{2}+\mathrm{O}_{2} \rightarrow \mathrm{SO}_{3}+\mathrm{O}$ in the temperature range 900-1350 K. J Inst Energy 57:373-376 (1984).

82. Mulcahy MFR, Steven JR, Ward JC and Williams DJ, Kinetics of interaction of oxygen atoms with sulfur oxides. Symp (International) Combust 12(1):323-330 (1969).

83. Mulcahy MFR, Steven JR and Ward JC, The kinetics of reaction between oxygen atoms and sulfur dioxide: an investigation by electron spin resonance spectrometry. J Phys Chem 71(7):2124-2131 (1967).

84. Yilmaz A, Hindiyarti L, Jensen AD, Glarborg P and Marshall P, Thermal dissociation of $\mathrm{SO}_{3}$ at 1000-1400 K. J Phys Chem A 110(21):6654-6659 (2006).

85. Merryman EL, Levy A. Enhanced $\mathrm{SO}_{3}$ emissions from staged combustion. In: Symp (International) Combust. 17(1):727-736 (1979).

86. Naidoo J, Goumri A and Marshall P, A kinetic study of the reaction of atomic oxygen with $\mathrm{SO}_{2}$. Proc Combust Inst 30(1):1219-1225 (2005).

87. Blitz MA, Hughes KJ and Pilling M, Determination of the high-pressure limiting rate coefficient and the enthalpy of reaction for $\mathrm{OH}+\mathrm{SO}$. J Phys Chem A 107(12):1971-1978 (2003).

88. Duan L, Duan Y, Sarbassov Y, Li Y and Anthony EJ, $\mathrm{SO}_{3}$ formation under oxyCFB combustion conditions. Int J Greenh Gas Control 43:172-178 (2015).

89. Belo LP, Elliott LK, Stanger RJ, Spörl R, Shah KV, Maier J et al., HighTemperature conversion of $\mathrm{SO}_{2}$ to $\mathrm{SO}_{3}$ : homogeneous experiments and catalytic effect of fly ash from air and oxy-fuel firing. Energy Fuels 28:7243-7251 (2014).

90. Fleig D, Alzueta MU, Normann F, Abián M, Andersson K and Johnsson F, Measurement and modeling of sulfur trioxide formation in a flow reactor under post-flame conditions. Combust Flame 160(6):1142-1151 (2013). 
91. Wang X, Liu X, Li D, Zhang Y and Xu M, Effect of steam and sulfur dioxide on sulfur trioxide formation during oxy-fuel combustion. Int J Greenh Gas Control 43:1-9 (2015).

92. Colorado State University. Chemical equilibrium calculation. Available at: http://navier.engr.colostate.edu/ dandy/code/code-4/index.html [accessed 15 September 2017].

93. Urbanek A, Trela M. Catalytic oxidation of sulfur dioxide. Catal Rev Sci Eng 21:73-133 (1980).

94. Marier $\mathrm{P}$, Dibbs HP. The catalytic conversion of $\mathrm{SO}_{2}$ to $\mathrm{SO}_{3}$ by fly ash and the capture of $\mathrm{SO}_{2}$ and $\mathrm{SO}_{3}$ by $\mathrm{CaO}$ and $\mathrm{MgO}$. Thermochim Acta 8(1-2):155-165 (1974).

95. Zhang X, Zhuang G, Chen J, Wang Y, Wang X, An Z et al., Heterogeneous reactions of sulfur dioxide on typical mineral particles. $J$ Phys Chem 110(25):12588-12596 (2006).

96. Tronconi E, Cavanna A, Orsenigo $\mathrm{C}$ and Forzatti $\mathrm{P}$, Transient kinetics of $\mathrm{SO}_{2}$ oxidation over SCR-DeNOx monolith catalysts. Ind Eng Chem Res 38(7):25932598 (1999).

97. Dunn JP, Koppula PR, Stenger HG and Wachs IE, Oxidation of sulfur dioxide to sulfur trioxide over supported vanadia catalysts. Appl Catal B Environ 19(2):103117 (1998).

98. Thibault JD. Steward FR and Ruthven DM, The kinetics of absorption of $\mathrm{SO}_{3}$ in calcium and magnesium oxides. Can J Chem Eng 60(6):796-801 (1982).

99. Galloway $\mathrm{BD}$, Sasmaz $\mathrm{E}$ and Padak $\mathrm{B}$, Binding of $\mathrm{SO}_{3}$ to fly ash components: $\mathrm{CaO}, \mathrm{MgO}, \mathrm{Na}_{2} \mathrm{O}$ and $\mathrm{K}_{2} \mathrm{O}$. Fuel 145:79-83 (2015).

100. Cao Y, Zhou H, Jiang W, Chen CW and Pan WP, Studies of the fate of sulfur trioxide in coal-fired utility boilers based on modified selected condensation methods. Environ Sci Technol 44(9):3429-3434 (2010).

101. Chang CC. Infrared studies of $\mathrm{SO}_{2}$ on $\gamma$-alumina. J Catal 53(3):374-385 (1978).

102. Jaworowski RJ, Mack SS. Evaluation of methods for measurement of $\mathrm{SO}_{3} / \mathrm{H}_{2} \mathrm{SO}_{4}$ in flue gas. J Air Pollut Control Assoc 29(1):43-46 (1979).

103. Fleig D, Vainio E, Andersson K, Brink A, Johnsson F and Hupa M, Evaluation of $\mathrm{SO}_{3}$ measurement techniques in air and oxy-fuel combustion. Energy Fuels 26:5537-5549 (2012).

104. ASTM D3226. Method of test for sulfur oxides in flue gases (barium chloranilate controlled condensation method). Withdrawn from 1978. Available at: http://www.astm.org/DATABASE.CART/WITHDRAWN/D3226.htm [accessed 27 August 2017].

105. BS 1756-4:1977, Methods for sampling and analysis of flue gases. Miscellaneous analyses. Withdrawn from 01 February 2008. Available at: http://shop.bsigroup.com/en/ProductDetail/?pid=000000000000052803 [accessed 27 August 2017]. 
106. NCASI Southern Regional Center, Method 8a-Determination of sulfuric acid vapor or mist and sulfur dioxide emissions from kraft recovery furnaces; pp.1-87, (1996). Available at: https://www3.epa.gov/ttnemc01/ctm/ctm-013.pdf [accessed 19 November 2017].

107. Maddalone RF, Newton SF, Rhudy RG and Statnick RM, Laboratory and field evaluation of the controlled condensation system for $\mathrm{SO}_{3}$ measurements in flue gas streams. J Air Pollut Control Assoc 29(6):626-631 (1979).

108. Dellinger B, Grotecloss G, Fortune CR, Cheney JL and Homolya JB, Sulfur dioxide oxidation and plume formation at cement kilns. Environ Sci Technol 14(10):1244-1249 (1980).

109. Cooper D. Optimization of a $\mathrm{NaCl}$ Adsorbent Tube Method for $\mathrm{SO}_{3}$ Measurements in Combustion Flue Gases. Report B-1177; Institute för Vattenoch Luftvardsforskning (IVL): Göteburg, (1995).

110. Kelman FN. Direct method on determination of the sulfuric acid in solution with sulfuric gases and air. Zavod Lab 11:1316-1318 (1952) (in Russian).

111. Vainio E, Fleig D, Brink A, Andersson K, Johnsson F and Hupa M, Experimental evaluation and field application of a salt method for $\mathrm{SO}_{3}$ measurement in flue gases. Energy Fuels 27:2767-2775 (2013).

112. Cooper $\mathrm{D}$, Andersson C. Determination of $\mathrm{SO}_{3}$ in flue gases using the $\mathrm{NaCl}$ method - a comparison with other techniques (Bestamning av $\mathrm{SO}_{3} \mathrm{I}$ rökgaser med NaCl-methoden - en jämförelse av olika metoder), Värmeforsk Report 616; (1994), (In Swedish).

113. Ibanez JG, Batten $\mathrm{CF}$ and Wentworth WE, Simultaneous determination of $\mathrm{SO}_{3}(\mathrm{~g})$ and $\mathrm{SO}_{2(\mathrm{~g})}$ in a flowing gas. Ind Eng Chem Res 47(7):2449-2454 (2008).

114. Fateev A, Clausen S. Sulfur trioxide on-line measurement technique for power plants. In: IEAGHG Workshop. Special Workshop on Oxyfuel Combustion. London, 25-26 January (2011). Available at: http://orbit.dtu.dk/files/10145781/Fateev_SO3_workshop_London.pdf [accessed 01 October 2017].

115. Continuous Measurement Technologies for $\mathrm{SO}_{3}$ and $\mathrm{H}_{2} \mathrm{SO}_{4}$ in Coal-Fired Power Plants, EPRI, Palo Alto, CA: 2004. 1009812.

116. Chamberlain S, Reeder T, Stimpson CK and Tree DR, A comparison of sulfur and chlorine gas species in pulverized-coal, air- and oxy-combustion. Combust Flame 160(11):2529-2539 (2013).

117. Roy B, Chen L and Bhattacharya S, Nitrogen oxides, sulfur trioxide, and mercury emissions during oxy-fuel fluidized bed combustion of Victorian brown coal. Environ Sci Technol 48(24):14844-14850 (2014).

118. Jackson PJ, Hilton DA and Buddery JH, Continuous measurement of sulphuric acid vapour in combustion gases using a portable automatic monitor. J Inst Energy 54:124-135 (1981).

119. $\mathrm{SO}_{3}$ Monitor. How much $\mathrm{SO}_{3}$ do you generate? Available at: http://www.pentol.net/_pdf/so3monitor-EN.pdf [Accessed 7 September 2017]. 
120. Dennis JS, Hayhurst AN. The formation of $\mathrm{SO}_{3}$ in a fluidized bed. Combust Flame 72(3):241-258 (1988).

121. Verhoff FH, Banchero JT. Predicting dew points of flue gases. Chem Eng Prog 70(8):71-72 (1974).

122. ZareNezhad B. New correlation predicts flue gas sulfuric acid dewpoints. Oil Gas $J$ 107(35):60-63 (2009).

123. Taylor HD. The condensation of sulphuric acid on cooled surfaces exposed to hot gases containing sulphur trioxide. Trans Faraday Soc 47:1114-1120 (1951).

124. Stuart DD. Acid dewpoint temperature measurement and its use in estimating sulfur trioxide concentration. Available at:

https://www.researchgate.net/profile/Derek_Stuart2/publication/265801421_Acid _dewpoint_temperature_measurement_and_its_use_in_estimating_sulfur_trioxide _concentration/links/59a0340c0f7e9b0fb8990820/Acid-dewpoint-temperaturemeasurement-and-its-use-in-estimating-sulfur-trioxide-concentration.pdf [accessed 05 November 2017].

125. Ahn J, Okerlund R, Fry A and Eddings EG, Sulfur trioxide formation during oxycoal combustion. Int J Greenh Gas Control 5S: S127-S135 (2011).

126. Fleig D, Andersson $\mathrm{K}$, Normann $\mathrm{F}$ and Johnsson $\mathrm{F}, \mathrm{SO}_{3}$ formation under oxy fuel combustion conditions. Ind Eng Chem Res 50(14):8505-8514 (2011).

127. Spörl R, Walker J, Belo L, Shah K, Stanger R, Maier J et al., $\mathrm{SO}_{3}$ emissions and removal by ash in coal-fired oxy-fuel combustion. Energy Fuels 28(8):5296-5306 (2014).

128. Belo LP, Elliott LK, Stanger RJ,Spörl R, Shah KV, Maier J et al., Laboratory investigations on the differences in the homogeneous and catalytic conversions with fly ash of $\mathrm{SO}_{2}$ to $\mathrm{SO}_{3}$ from air and oxy-fuel PF combustion. In: Impacts of Fuel Quality on Power Production. 26-31 ${ }^{\text {st }}$ October, Snowbird, Utah (2014).

129. Zheng L, Furimsky E. Assessment of coal combustion in $\mathrm{O}_{2}+\mathrm{CO}_{2}$ by equilibrium calculations. Fuel Process Technol 81(1):23-34 (2003).

130. Armitage JW, Cullis CF. Studies of the reaction between nitrogen dioxide and sulfur dioxide. Combust Flame 16(2):125-130 (1971).

131. Wendt JOL, Sternling CV. Catalysis of $\mathrm{SO}_{2}$ oxidation by nitrogen oxides. Combust Flame 21(3):387-390 (1973).

132. Kühnemuth D, Normann F, Andersson $\mathrm{K}$ and Johnsson F, On the carbon monoxide formation in oxy-fuel combustion - Contribution by homogenous and heterogeneous reactions. Int J Greenh Gas Control 25:33-41 (2014).

133. Seddighi S, Pallarès D, Normann F and Johnsson F, Carbon monoxide formation during oxy-fuel-fired fluidized-fed combustion. Energy Fuels 27(4):2275-2282 (2013).

134. Glarborg P, Bentzen LLB. Chemical effects of a high $\mathrm{CO}_{2}$ concentration in oxyfuel combustion of methane. Energy Fuels 22:291-296 (2007).

135. Bayless DJ, Jewmaidang J, Tanneer S and Birru R, Kinetics of low-temperature homogeneous $\mathrm{SO}_{3}$ formation for use in flue gas conditioning for improved 
electrostatic precipitator performance. In: Proceedings of the Combustion Institute 28:2499-2505 (2000).

136. Hecht ES, Shaddix CR, Geier M, Molina A and Haynes BS, Effect of $\mathrm{CO}_{2}$ and steam gasification reactions on the oxy-combustion of pulverized coal char. Combust Flame 159(11):3437-3447 (2012).

137. Wine PH, Thompston RJ, Ravishankara AR, Semmes DH, Gump CA, Torabi A et al., Kinetics of the reaction $\mathrm{OH}+\mathrm{SO}_{2}+\mathrm{M} \rightarrow \mathrm{HOSO}_{2}+\mathrm{M}$. Temperature and pressure dependence in the falloff region. J Phys Chem 88(10):2095-2104 (1984).

138. Hindiyarti L, Glarborg $\mathrm{P}$ and Marshall $\mathrm{P}$. Reactions of $\mathrm{SO}_{3}$ with the $\mathrm{O} / \mathrm{H}$ radical pool under combustion conditions. J Phys Chem A 111(19):3984-3991 (2007).

139. Flint D, Lindsay AW. Catalytic oxidation of sulphur dioxide on heated quartz surfaces. Fuel 30:288 (1951).

140. Crumley PH, Fletcher AW. The formation of sulphur trioxide in flue gases. $J$ Inst Fuel 29:322-327 (1956).

141. Barret RE, Hummell JD and Reid WT, Formation of $\mathrm{SO}_{3}$ in a noncatalytic combustor. J Eng Power 88:165-172 (1966).

142. Couling D. Impact of oxyfuel operation on emissions and ash properties based on E.ON's 1MW CTF. In: IEAGHG Special Workshop on Oxyfuel Combustion, 2526 January, London (2011).

143. Kenney JR, Clark MM, Levasseur AA and Kang SG, $\mathrm{SO}_{3}$ emissions from a tangentially- fired pilot scale boiler operating under oxy-combustion conditions. In: IEAGHG Special Workshop on Oxyfuel Combustion, 25-26 January, London (2011).

144. Jurado N, Darabkhani HG, Anthony EJ and Oakey JE, Oxy-combustion studies into the co-firing of coal and biomass blends: effects on heat transfer, gas and ash compositions. Energy Procedia 63:440-452 (2014).

145. Spörl R, Belo L, Shah K, Stanger R, Giniyatullin R, Maier J et al., Mercury emissions and removal by ash in coal-fired oxy-fuel combustion. Energy Fuels 28(1):123-135 (2014).

146. Spörl R, Maier J and Scheffknecht G, Experiences and Results of $\mathrm{SO}_{3}$ measurements performed under oxy-coal fired conditions. In: IEAGHG Special Workshop on Oxyfuel Combustion, 25-26 January, London (2011).

147. Mönckert $P$, Dhungel B, Kull R and Maier J, Impact of combustion conditions on emission formation $\left(\mathrm{SO}_{2}, \mathrm{NO}_{\mathrm{x}}\right)$ and fly ash. In: 3rd meeting of the oxy-fuel combustion network. Yokohama Symposia, Yokohama, Japan: IEA Greenhouse Gas R\&D programme (2008).

148. Mitsui $\mathrm{Y}$, Imada $\mathrm{N}$, Kikkawa $\mathrm{H}$ and Katagawa $\mathrm{A}$, Study of $\mathrm{Hg}$ and $\mathrm{SO}_{3}$ behavior in flue gas of oxy-fuel combustion system. Int J Greenh Gas Control 5S:S143S150 (2011).

149. Eddings EG, Wang $\mathrm{L}$ and Ahn J, Bench-scale fluid bed experiments of $\mathrm{SO}_{2} / \mathrm{SO}_{3}$ formation and sulfur capture in $\mathrm{N}_{2} / \mathrm{O}_{2}$ and $\mathrm{SO}_{2} / \mathrm{O}_{2}$ environments. In: IEAGHG 
Special Workshop on $\mathrm{SO}_{2} / \mathrm{SO}_{3} / \mathrm{Hg} /$ Corrosion Issues in Oxycoal Combustion Boiler and Flue Gas Processing Units, 25-26 January, London (2011).

150. Spörl R, Maier J, Belo L, Shah K, Stanger R, Wall T et al., Mercury and $\mathrm{SO}_{3}$ emissions in oxy-fuel combustion. In: Energy Procedia 63:386-402 (2014).

151. Davis C. Impact of oxyfuel operation on corrosion in coal fired boilers based on experience with E.ON's 1MWth Combustion test facility. In: IEAGHG Special Workshop on Oxyfuel Combustion, 25-26 January, London (2011).

152. Stanger R, Belo L, Ting $\mathrm{T}$, Spero $\mathrm{C}$ and Wall $\mathrm{T}$, Mercury and $\mathrm{SO}_{3}$ measurements on the fabric filter at the Callide Oxy-fuel Project during air and oxy-fuel firing transitions. Int J Greenh Gas Control 47:221-232 (2016).

153. Glarborg P, Alzueta MU, Dam-Johansen K and Miller JA. Kinetic modeling of hydrocarbon/nitric oxide interactions in a flow reactor. Combust Flame 115(12):1-27 (1998).

154. Schneider DR, Bogdan Z. Modelling of $\mathrm{SO}_{3}$ formation in the flame of a heavy-oil fired furnace. Chem Biochem Eng $Q$ 17(3):175-181 (2003). 